\title{
Global Supply Chains and Macroeconomic Relationships in Asia
}

\author{
By \\ Menzie D. Chinn \\ University of Wisconsin and NBER
}

November 12, 2013

\begin{abstract}
The macroeconomic implications of increasing vertical specialization in East Asia are assessed. These implications range from the measurement issues (real exchange rates), the impact on exchange rates on trade flows, and exchange rate pass through. The ramifications for business cycle synchronization are also discussed. Finally, the changing nature of central bank exchange rate management is evaluated.
\end{abstract}

JEL classification: F31, F41

Acknowledgments: Paper prepared for the ADB Conference on Global Supply Chains and Trade in Value Added. I thank David Hummels for very helpful comments. All remaining errors remain solely my responsibility.

* Robert M. La Follette School of Public Affairs; and Department of Economics, University of Wisconsin, 1180 Observatory Drive, Madison, WI 53706-1393. Email: mchinn [at] lafollette.wisc.edu 


\section{Introduction}

One of the key challenges to the analysis of open economy macroeconomic interactions involves the understanding of how flows in goods and services, capital and asset prices respond in a world where trade is not limited to final goods, but includes (potentially many) stages of intermediate production. That is particularly true in parts of the world deeply involved in trade in global supply chains - the phenomenon wherein a final good is produced in separate countries. Nowhere has this process of production fragmentation extended as far as in East Asia. Hence, the need for an examination of the macroeconomic implications for the region.

In this chapter, I survey the various channels by which economic interactions might evolve with increasing integration. First, I assess the implications for the measurement of macroeconomic variables, in particular the real exchange rate - the relative price of traded goods and services - will become more difficult to measure. One can no longer merely appeal the final good prices to deflate the nominal exchange rate; rather one would need to keep track of the value added at each stage of production - and where it took place.

Second, I assess the ramifications for the measurement of the relationship between exchange rates and trade flow, when relative prices and trade flows are properly measured.

Third, the impact of greater vertical specialization on exchange rate pass through into traded goods prices is examined.

Fourth, I assess the evidence on business cycle synchronization. With production fragmented across economies, in principle an additional channel has been added to the other means by which shocks are propagated across economies.

Finally, I investigate the conjecture that increasing integration by way of global supply chains will lead to increasing motivation for policymakers to stabilize nominal exchange rates, insofar as exchange rate volatility complicates planning and production in integrated production chains.

The following conclusions stem from the survey. 
First, the conventional means of measuring international competitiveness are going to be less and less adequate, as production becomes more fragmented. Relatedly, it will become less and less tenable to estimate the traditional partial equilibrium trade equations, in order to obtain macro-level trade elasticities, as mis-measurement of trade flows becomes more pronounced, and appropriate deflators for real exchange rates diverge further from the typically used deflators.

Second, the increasing role of intermediate inputs will likely drive down exchange rate pass through. This is true even if the increase is due to increasing arms-length transactions. However, to the extent that pass through is less pronounced the greater the amount of intrafirm trade, a further decrease in exchange rate pass through is likely to occur.

Third, business cycle correlations are rising throughout the region. The more prominent increases are often associated with China, a finding consistent with China's growing role in the global supply chain. Furthermore, the propagation of shocks throughout the East Asia system is consistent China driving movements in output, at least in Korea and Taiwan.

Finally, there is evidence that the central banks of the region are paying more heed to the Chinese currency's value. This is true at the high frequency (daily) and at lower frequency (monthly); it's true with respect to rates of depreciation, as well as levels of exchange rates. Since these relationships are not structural, there is no guarantee that they will remain in place. At the same time, continued integration by way of production fragmentation should make central bankers pay extra heed to stabilizing currency values against each other.

\section{The Measurement of the Real Effective Exchange Rate}

The real exchange rate occupies a central role in international finance as the key relative price between home and foreign goods. In a world where trade is in final goods, and all goods are traded, the real exchange rate definition is relatively clear:

$$
q_{t} \equiv s_{t}-p_{t}+p_{t}^{*}
$$


Where $s$ is the log nominal exchange rate expressed in home currency units per foreign, and $p$ is the log price level for home final goods, and $p^{*}$ for foreign final goods. Then $q$ denotes the number of home units of final goods necessary to obtain one unit of foreign.

This simple expression can be complicated in a number of ways, depending upon whether there are nontraded goods, or whether final goods are the only goods traded. ${ }^{1}$ The fact that there are multiple countries should not complicate the expression terribly. Then the real exchange rate is a weighted average of the exchange rates and price levels corresponding to the various trade partners. The complication involves what weights to attribute to each bilateral real exchange rate. ${ }^{2}$

The correct definition of the real exchange rate is altered when there is trade in intermediate goods. Then one can ask either of two questions. The first is whether agents have preferences over the value added originating in different countries, or preferences over final goods. This distinction is sometimes characterized as the difference between trade in tasks versus trade in goods.

Let's consider the first approach. Then, the appropriate definition of the relative price of traded output is the relative price of value added expressed in common currency terms. In practical terms, this greatly complicates the calculation of the relative price. Now one has to keep track of where inputs come from, and measure the appropriate price deflators for the amount of value added actually incorporated into the good in a given country.

Bems and Johnson argue that the conventional real effective exchange rates incorporating prices of gross sales does not conform to any theoretically justified measure - not even one in which goods are produced without imported intermediates. In addition, the popular expedient of using consumer price indices instead of price indices of the goods traded introduces another possible difference. Of course the relevant question is whether in practice the conventional measures deviate substantially from the theoretically more correct measures.

\footnotetext{
${ }^{1}$ See Chinn (2006) for a discussion of the various different concepts of the real exchange rate. In general, intermediates are not directly accounted for.

2 The conventional approach uses trade weights for traded goods, assuming goods are differentiated by location.
} 
In practice, Bems and Johnson find that in many cases the appropriate effective exchange rates do differ from the conventionally used ones. However, the difference are most pronounced for exactly those instances wherein one would expect the biggest differences China, Germany, other East Asian economies. Figures 1-3 depict the conventional (IMF) real effective exchange rates and the Bems-Johnson value added counterparts for China, Japan and Korea (all graphed so that a rise denotes an appreciation).

Interestingly, the big differences in the real exchange rate values are not driven by the adjustment in trade weights. Rather the main factor is in the use of a value-added deflator, rather than the CPI. It's always been known that the use of the CPI is likely to lead to mistaken inferences regarding relative prices due to the heavy weight adduced to services and other nontraded goods in CPIs. ${ }^{3}$

For instance, over the 1995-2009 period, the Chinese effective exchange rate appreciated $15 \%$ more than was implied using the conventional (CPI, trade weighted) measure (Figure 1). ${ }^{4}$ Relative to 2000 , the differential is $20 \%$. Had this result been known in 2005-06, the controversy over RMB misalignment might have been less heated. Interestingly, most of the difference is attributable not to the difference in trade weights, but rather to the difference in use of deflator. ${ }^{5}$

Japan is another case of a country deeply involved in the East Asian global supply chain. In this instance, as of 2009, the cumulative gap between the conventional and value added series amounted to $20 \%$-- that is the yen depreciated $20 \%$ more after taking into account intermediate goods and the correct deflator than was indicated using the conventional measure. This result casts in a different light the increase in the trade balance in the years leading up to the global financial crisis; apparently the improvement was driven by a greater

\footnotetext{
${ }^{3}$ There is a tradeoff between the use of the theoretically correct measures and the conventional ones. The former requires detailed data on trade flows and from input-output tables. Substantial measurement error is likely to be introduced as a consequence.

${ }^{4}$ The sharp move in 1994 should be treated with caution, as the series is calculated using official rates. Fernald et al. (1999) document the fact that pre-1994, many transactions were taking place at a different "swap" rate.

${ }^{5}$ This leads to the question whether simply using GDP deflators would mitigate the problem substantially.
} 
than measured yen depreciation. The Korean value added measure also shows a less pronounced appreciation than the conventional measure (Figure 3).

Notice the correct deflator is not the deflator for all of GDP, but for the value added component imbedded in traded goods. The two might move together, but there are no guarantees. CPIs are likely to deviate even further from the ideal deflator.

The Bems-Johnson approach focuses on value added. An alternative approach is to view the trade as driven by preferences over final goods - that is the price of the final good, taking into account the price savings due to outsourcing of production is key. This approach is taken up by Bayoumi, et al. (2013).

In this approach, one wants to take into account the costs along the entire production chain, i.e., taking into account outsourcing of production. As mentioned before, this approach makes more sense if preferences are expressed over goods, rather than value-added. Bayoumi et al. (2013) implement this alternative approach and show that the impact vis a vis the BemsJohnson formulation is in several cases minor. On the other hand, in the case of China, use of outsourcing means that the appreciation in the value of final goods is less than the appreciation in terms of tasks. This approach is consistent with the Thorbecke (2011) measurement of the integrated exchange rate measure for China, which incorporates information on inputs from other East Asian countries in the production of Chinese exports.

On the other hand, for the United States, the difference is negligible. Finally there are intermediate cases such as Germany, where the trade-in-tasks and trade-in-goods measures deviate sometimes, and at other times, does not. ${ }^{6}$

To the extent that competitiveness is appropriately defined over the value added component of exports and imports, this issue of measurement is quantitatively important in the East Asian region.

\footnotetext{
${ }^{6}$ Koopman, Wang and Wei (2012) approach the issue of measuring vertical specialization, defined in various ways, in a manner that nests some of the other approaches. Their approach incorporates measurement of domestic value added that is incorporated in imports used in exports.
} 


\section{Assessing the Implications for Trade Flows}

\subsection{Background}

One of the reasons that one would want to measure correctly exchange rates is so that one could obtain accurate measures of competitiveness, and hence of the responsiveness of trade flows to price changes.

The typical macroeconomists' approach is to assume that one can estimate trade elasticities in a partial equilibrium framework following the "imperfect substitutes" methodology outlined in, for instance, Kahn and Goldstein (1985). That is, one can write out export and import equations (assuming log-linear functional forms, where lowercase letters denote log values of upper case):

$$
\begin{aligned}
& e x_{t}=\delta_{0}+\delta_{1} q_{t}+\delta_{2} y_{t}^{R o W}+\delta_{3} z_{t}^{i}+\varepsilon_{1 t} \\
& i m_{t}=\beta_{0}+\beta_{1} q_{t}+\beta_{2} y_{t}^{i}+\beta_{3} z_{t}^{R o W}+\varepsilon_{2 t}
\end{aligned}
$$

Where $y$ is income, $z$ is a supply (shift) variable, and $\beta_{1}<0, \beta_{2}>0, \beta_{3}>0$ and $\delta_{1}>0, \delta_{2}>0, \delta_{3}>$ 0.

Notice that exports are the residual of production over domestic consumption of exportables; similarly imports are the residual of foreign production over foreign consumption of tradables. The difference between this specification and the standard is the inclusion of the exportables supply shift variable, $z$. In standard import and export regressions, this term is omitted, implicitly holding the export supply curve fixed; in other words, it constrains the relationship between domestic consumption of exportables and production of exportables to be constant. A bout of consumption at home that reduces the supply available for exports would induce an apparent structural break in the equation (2) if the $z$ term is omitted. Similarly, 
omission of the rest-of-world export supply term from the import equation makes the estimated relationships susceptible to structural breaks. ${ }^{7}$

The preceding estimation procedure proceeds assuming that the export and import equations can be estimated separately. This would be most appropriate if trade was in final goods, but clearly this is a less and less tenable proposition over time. Johnson (forthcoming) summarizes the prevailing estimates: about exports of value added are equal to about $70-75 \%$ of gross exports, down from about $85 \%$ in the $1970-80$ 's.

The foregoing is a reduced form approach. As documented in Hillberry and Hummels (2012), estimation of such reduced form equations is typically plagued by endogeneity issues (as well as measurement error). To the extent that the relative price variable is the real exchange rate, which incorporates the nominal exchange rate, the problem is mitigated. In the typical econometric exercise, the real exchange rate is weakly exogenous for trade flows. ${ }^{8}$

In the macroeconomic literature, most attempts to deal with the issue of vertical specialization have been ad hoc in nature. In addressing U.S. trade, for instance, Chinn (2010) takes an indirect approach. He adduces the high income elasticities to production fragmentation, which is turn increasing as tariffs are reduced, following (Hummels, et al., 2001; Yi, 2003; Chen et al., 2005). At this juncture, it is useful to recognize that services exhibit less of this fragmentation. ${ }^{9}$

Chinn finds that the tariff factor and the square both enter with statistical significance, indicating that lower tariffs increase trade flows. However, as expected higher energy costs, as proxied by the relative price of oil, also enters in. These findings are indirectly supportive of the

\footnotetext{
7 The problem, of course, is obtaining good proxies for these supply terms. In the some previous studies, a measure of the U.S. capital stock has been used. Obvious candidates, such as US industrial production for US exports, exhibits too much collinearity with rest-of-world GDP to identify the supply effect precisely. That is why this supply factor has typically been identified in panel cross section analyses (Bayoumi, 2003; Gagnon, 2004). ${ }^{8}$ For instance, as in Chinn (2004).

${ }^{9}$ Barrell and Dées (2005) and Camerero and Tamarit (2003) address the issue of very high income elasticities by incorporating FDI into the specifications. IMF (2007) incorporates exports of intermediates in the import equation, and imports of intermediates in the export equation, to account for vertical specialization. This procedure reduces the estimated income elasticities.
} 
view that vertical specialization is important. So too is the fact that income elasticities differ substantially for durables and nondurables, particularly on the US export side.

Clearly, the results pertaining to the United States, with relatively low levels of vertical specialization in trade flows, is of some, but limited, relevance. ${ }^{10}$ Perhaps the most important instance would be the Chinese case. In their study of Chinese imports and exports, Cheung, Chinn and Fujii (2010) and Cheung, Chinn and Qian (2012) follow previous studies by incorporating an ad hoc correction. This involves adding processing imports into the export equation, and exports into the processing imports equation.

Cheung et al. (2012) consider Chinese trade flows with respect to the rest-of-the-world, using the Chinese version of equations (2) and (3). Then $q$ is the real value of the RMB, and $z^{\text {Row }}$ replaced with $w$ in the import equation. The variable $w$ is a shift variable accounting for other factors that might increase import demand. Because of China's role in the global supply chain, it is assumed that a fraction of imports is intermediate goods and its demand is driven by export activity; hence $w$ could include exports. ${ }^{11}$

In order to account for China's role in the global supply chain, they include exports as an independent variable. ${ }^{12}$ Exports enter in with the expected sign (and a near unit elasticity). However, the real exchange rate retains a negative and significant coefficient.

Another way to address the supply chain effect is to disaggregate the trade flows. The Chinese customs agency categories exports and imports into those goods that are to be used for processing purposes, and those to be used as ordinary exports or imports. For instance, processing imports are usually for manufacturing finished products in China for (re-)exporting

\footnotetext{
${ }^{10}$ Although even for the United States, the impact of vertical specialization is measurable. As shown in Figure 8 , the conventional and value added measures deviate by about 10\% from 1995 to 2009.

${ }^{11}$ One particularly difficult issue involves price deflators to use to convert nominal magnitudes into real. Until 2005, the Chinese did not report price indices for imports and exports; this limits the sample to one far too short to use in the analysis. Hence, we rely upon a variety of proxy measures, each with some drawbacks. Since the trade flows are reported in US dollars, the price measures we consider include the US PPI for finished goods, price indices from the World Bank, and Hong Kong re-export unit value indices. We only report results based upon the last deflator; the remaining results are qualitatively similar to those reported, and are available upon request. 12 It could be argued that we should use processing exports instead of total exports. Substituting one for the other does not lead to any consequential changes in the results. We conjecture that this is the case because the two series share the same trajectory. See Figure 3 in Cheung, Chinn, and Qian (2012).
} 
and these imports are usually subjected to more favorable tariff rates. In contrast, processing exports are exports that are used by the imported country for processing and assembly.

For both ordinary and processing exports, the typical result is that the value of the RMB enters in with the right sign and statistical significance. One large difference is the fact that ordinary exports do not exhibit a statistically significant sensitivity to rest-of-world GDP (unless a post-WTO trend is included. In contrast, processing exports always exhibit income elasticities in excess of unity.

Next, they investigate whether the corresponding disaggregation yields some more promising results for imports. For ordinary imports, the income elasticity is positive but not statistically significant, while the exchange rate has the wrong effect. If one includes exports (which is not well motivated for ordinary imports), the results are largely negative as well, since no economic variable enters with significance.

For processing imports, both income and the real exchange rate enter significantly, but the latter enters with the wrong sign. Including exports results in properly signed coefficients for the exchange rate and export variables. Income now enters with a negative, and significant, sign. These results demonstrate that obtaining a correctly signed price elasticity depends on accounting, however imperfectly, for imported inputs.

\subsection{Using the "Correct" Real Exchange Rate Measure}

An ideal approach would estimate a relationship between the trade flows and the real exchange rate, measured in consistent terms. As Johnson (forthcoming) observes, there are two ways to proceed. The first is to work with a model couched in terms of value added (including preferences over value added). Another is to remain in the final goods framework, and work backward to calculate the amount of value added at various stages of production. In the absence of that data, one can return to the ad hoc procedure used by Cheung et al. If one estimates a relationship of the nature reported in Table 1 (imports as a function of income, real exchange rate, exports and a time trend), over the 2000Q1-09Q4 period, using the conventional real exchange rate measure, one obtains an estimated (and statistically significant) import 
elasticity of 1.5; that is an appreciation of the RMB induces a decrease in imports, even after controlling (imperfectly) for the export motivation. Using the Bems-Johnson real exchange rate measure, the point estimate drops to 0.6 , and is no longer statistically significant.

In the case of the China, the use of a value added real exchange rate helps to eliminate a strongly perverse finding. This suggests that, contrary to some findings (including Cheung et al.), trade flows (even mis-measured) do respond to real exchange rate changes.

Whether in fact the true underlying trade elasticities have changed is a separate matter that cannot be determined from these data. With exchange rate changes operating only on value added, rather than on gross sales, it is tempting to conclude that the measured impact on trade flows will be less. The canonical example is the case wherein imported inputs are used to produce an exported good. In that case, an exchange rate depreciation raises the price of export (for simplicity one-for-one), but also increases the price of the imported input (for simplicity, one-for-one again). Then the exchange rate depreciation only affects the relative price of the value added. The true impact (on value added) should be unchanged, but will appear to be smaller over time as vertical specialization proceeds, holding all else constant. Thorbecke and Smith $(2010,2011)$ estimate the impact of exchange rate changes on gross trade flows, taking into account intermediate trade flows. ${ }^{13}$

What about evaluating bilateral trade elasticities? Here, the analysis becomes more complicated, as one cannot simply examine the bilateral trade, activity and price variables. ${ }^{14}$ The response of one country's exports to a change in the nominal exchange rate will have different effects if, for instance, three countries are involved in production sharing. If the RMB appreciates against a currency of a country from which it imports

\footnotetext{
${ }^{13}$ See Thorbeck (2006) for an examination of the impact of a yuan appreciation on the US-China trade balance, taking into account imported intermediate goods.

${ }^{14}$ Obviously, at a minimum, this approach would require correct measurement of bilateral trade flows. Koopman, Wang and Wei (2012) show that in many instances, particularly involving East Asia, gross and value added trade balances can differ substantially.
} 
intermediate goods to be used in exports to the US, the gross price of Chinese goods exported to the US will likely fall even if the bilateral dollar-yuan rate has not changed. This will then have an impact on demand for Chinese value added, even if the original shock did not involve a change in Chinese value added. ${ }^{15}$

\section{Exchange Rate Pass Through}

\subsection{Background}

Exchange rate pass through is the relationship between trade prices (or consumer prices) and exchange rates. Increased vertical specialization is likely to reduce pass through, according to various models, although the effect is likely to be difficult to detect in the welter of other effects.

The standard approach to explaining exchange rate pass through (e.g., Hooper and Mann, 1989) appeals to imperfect competition, but without explicit microfoundations. Let $P_{X}{ }^{*}$ be the price of exports from the foreign $\left({ }^{*}\right)$ country, denominated in foreign currency; and $C^{*}$ be the marginal cost of production (also in foreign currency terms).

$$
P_{x}^{*}=\mu C^{*}
$$

Where $\mu$ is the cost-markup. The US import price $\left(P M^{i}\right)$ is obtained by multiplying through by the exchange rate ( $E$, in currency $\mathrm{i} /$ foreign currency unit, e.g., Korean won/US\$):

$$
P M^{i}=E\left(P X^{*}\right)=E \mu C^{*}
$$

Where the markup, $\mu$, depends on the degree of substitutability between US and imported goods, and capacity utilization in the foreign country, as in:

$$
\mu=\left(\frac{P^{i}}{C^{*} E}\right)^{\alpha}\left(C U^{*}\right)^{\beta}
$$

where $p^{i}$ is the average local price level in local currency of the good in question. Solving, and taking logs yields:

15 This example is a modification of an example in Johnson (forthcoming). 


$$
p m^{i}=(1-\alpha) e+\alpha p^{i}+(1-\alpha) c^{*}+\beta c u^{*}
$$

Note that $\partial p_{m}{ }^{i} / \partial e \equiv(1-\alpha) \equiv$ exchange rate pass-through (where $\partial$ denotes partial derivative).

Further observe that the expression has implications for foreign firms' (log) markup:

$$
p m^{\$}-e-c^{*}=\alpha\left(p^{\$}-e-c^{*}\right)+\beta c u^{*}
$$

so that the log markup or profit margin on sales to the US is a function of gap between the US price and foreign cost. When $\alpha$ is near unity (or pass-through is low) then a rise in $e$ causes a decline in foreign profit margins. ${ }^{16}$

Note three limitations. First, the exposition above relies upon all value added originating in a given country. Second, most of the studies of exchange rate pass through have focused on industrialized countries. Third, these studies focused on macroeconomic determinants (most importantly, inflation). Within this literature, the evidence in the years before the financial crisis documented a decline in industrial country exchange rate pass through. These studies included a comprehensive analysis by the Federal Reserve of U.S. import prices (Marazzi et al., 2005), and industrial countries generally (Sekine, 2006). Bailliu and Fujii (2004) attribute the drop to the decline in trend inflation.

The development of open economy New Keynesian models has focused attention on the relationship between exchange rate pass through and whether pricing is undertaken in producer currency or local currency. Local currency pricing is consistent with incomplete pass through into import prices. The fact that export price pass through is also less than complete suggests to Choudhri and Hakura (2012) that there is a mixture of producer currency and local currency pricing occurring for both exports and imports.

There is, of course, an endogeneity issue. Gopinath, Iskhoki and Rigobon (2010) show that the selection of pricing currency depends upon the desired level of exchange rate pass

\footnotetext{
${ }^{16}$ Estimates of exchange rate pass through for industrial countries are around 0.5, according to Campa and Goldberg (2005). Long run pass-through of $50 \%$ implies that long-run profit margins for foreign exporting firms sustain extremely large shifts if wages are sticky in the local currency.
} 
through. This is the topic of some recent analyses, which have focused on the microeconomic aspects of exchange rate pass through. In particular, increasing vertical specialization should, on average reduce exchange rate pass through. That's because, with imported inputs, an exchange rate change will change marginal costs, as illustrated in the example in the previous section. Hellerstein and Villas-Boas (2010) and Neiman (2010) document the fact that exchange rate pass through varies inversely with the intensity of vertical specialization for U.S. imports. Of the $\$ 16$ trillion of gross world trade in 2010, roughly $\$ 6.3$ trillion is intrafirm in nature, so presumably this phenomenon extends to other currencies and trade flows (UNCTAD, 2013).

\subsection{Application to East Asia}

Ghosh and Rajan (2007) survey the literature on exchange rate pass through in Asia, and find a wide dispersion of estimates, ranging from relatively high for developing Asian economies such as Thailand and Indonesia, and substantially lower for industrial Japan. The dispersion of estimates is not unexpected given the wide diversity of exchange rate regimes (and relatedly, inflation outcomes).

Choudhri and Hakura (2012) provide some recent estimates of import and export exchange rate pass through, obtained using VARs over the 1979-2010 period. Estimates for selected East Asian economies are presented in Figures 4.1 and 4.2, for import and export pass through estimates, respectively. ${ }^{17}$ While the estimates for Hong Kong and Singapore indicate very low import pass through coefficients, in accord with the predictions, those for Thailand and Singapore exceed the average for emerging market economies. This suggests that, for now at least, macroeconomic factors (inflation, exchange rate regime) trump micro factors.

Amiti, Itskhoki and Konings (2012) provide a microeconomic based explanation to expect exchange rate pass through to be particularly muted. They note that oftentimes large exporters are large importers. In such instances, in the presence of strategic complementarities and high market shares, exchange rate pass through will tend to be small. To the extent that this characterization applies to East Asian firms, then one would expect the relatively low

\footnotetext{
${ }^{17}$ Regression based estimates are of similar magnitudes.
} 
exchange rate pass through coefficients make sense, holding all else constant. However, with the exception of Hong Kong and Singapore, pass through coefficients appear fairly high, which suggests that other macroeconomic factors which have been determined to be important (inflation, exchange rate regime) trump micro factors. Nonetheless, to the extent that the process of vertical specialization continues, then pass through coefficients should decline over time. $^{18}$

\section{Synchronization of Business Cycles}

\subsection{Business Cycles}

During the Great Recession, output in East Asia was hit particularly hard as trade flows dropped precipitously. Several hypotheses were forwarded for why trade fell so much more than output, including the drying up of trade financing, a composition effect (hard hit durables are much more procyclical than nondurables), and the importance of vertical specialization. ${ }^{19}$ On this point there is no complete agreement, but it at least seems to be a plausible argument that high degrees of vertical specialization will induce greater business cycle comovement.

Kose and Yi (2001) are an early expositor of the view that greater vertical specialization leads to greater business cycle synchronization. More recently Burstein et al. (2008) have argued that vertical specialization is an important determinant of synchronization. Arkolakis and Ramanarayanan (2009) show that GDP growth will become more synchronized if imperfect competition prevails.

Carare and Mody (2012) undertake a recent empirical analysis of this hypothesis. In it, they relate volatility spillovers and the extent of vertical specialization, for a sample of eighteen countries, over the 1977-2007 period. First, they estimate a factor structural VAR (Stock and Watson, 2005). The FSVAR allows for a decomposition of the variance of the shocks into domestic shocks and common international shocks that affect all countries in the same quarter.

\footnotetext{
${ }^{18}$ Ito and Chinn (2013) document the rapid rise in RMB invoicing in Chinese trade. To the extent this is a largely exogenously driven process, exchange rate pass through should be expected to decline over time, holding all else constant.

${ }^{19}$ See Baldwin (2009) for a summary of competing views.
} 
Spillovers have a specific interpretation -country-specific shocks that affect other countries after one quarter.

The degree of vertical specialization is taken from the OECD's Measuring Globalization publication, and is the share of imported inputs in exports. They document a clear positive association between the change in growth spillovers and the change in vertical specialization over the 1995-2000 period; when the change in vertical specialization between 1995 and 2000 rises by one percent, the change in the share of spillovers in volatility rises by 0.92 units. The bivariate relationship between vertical specialization and spillovers is stronger than that between trade intensity and spillovers (the partial effect is not discernable due to multicollinearity).

One drawback of this approach is that the link is between vertical specialization in the form of imports used for overall exports, and overall sensitivity to spillovers from the rest of the world. That is, there is no direct relationship between bilateral vertical specialization and the spillover from a particular trading partner. ${ }^{20}$

$\mathrm{Ng}$ (2010) examines a sample of 30 OECD countries over the 1970-2004 period, but investigates the relationship between bilateral correlation and bilateral trade linkages. He regresses bilateral GDP correlation coefficients, derived from HP-filtered GDP, on two measures of vertical specialization - the imported input share of gross output (weighted using either exports or output). Controls for intra-industry trade, trade intensity, similarity in industrial structure, and financial integration (all bilateral). While the standard variables, such as trade intensity and intra-industry trade, matter, the latter loses significance when the vertical specialization measures are included; in addition, trade intensity takes on the wrong sign.

Di Giovanni and Levchenko (2012) examine a larger, more detailed dataset that encompasses 55 countries, 28 manufacturing sectors, over the 1970-1999 period. They use a decomposition of the correlation of output growth correlation into correlations between sector

\footnotetext{
${ }^{20}$ In addition, most of the sample involves OECD countries, and includes only two East Asian countries (Japan and Korea).
} 
growth correlations. They find that for this sample, vertical linkages account for $32 \%$ of the impact of bilateral trade on aggregate comovement of GDP growth, a share that is consistent with previous studies such as Burstein et al. (2008).

In interpreting these results in the context of East Asia, several caveats are necessary. Ng's sample only includes four East Asian countries: Japan, Korea, China, Indonesia, and Taiwan. The di Giovanni and Levchenko study includes a greater number of East Asian countries - adding in Hong Kong, Malaysia and Singapore, but omitting China. Perhaps more importantly, the vertical integration statistics apply to either before 2000 , or up to 2000 . In other words, most of the relationship between vertical specialization and business cycle correlation that is documented pertains to the extent of linkages in place over a decade ago.

This suggests that it might be useful to examine more recent trends in business cycle dynamics, under the presumption that the links have become stronger over time.

\subsection{Recent Trends in East Asian Business Cycle Dynamics}

In this section, I document the changes in business cycle dynamics over the past thirty years. In the absence of recent data on the extent of bilateral vertical specialization for all the relevant countries in the region, I limit myself to documenting the business cycle dynamics.

To this end, I examine the time series properties of real GDP in the region, utilizing quarterly data over the 1980Q1-2012Q4 period. The use of quarterly data allows for a more detailed view of business cycle dynamics. I focus on the newly industrialized countries (NICs), of Hong Kong, Korea, Singapore and Taiwan, and the emerging Asian economies of China, Indonesia, Malaysia, Philippines and Thailand. I check the correlations with Japan, the US, and for comparison's sake, Mexico.

In order to isolate the business cycle components, I employ several statistical techniques: a Hodrick-Prescott filter, quadratic detrending, and log-differencing. ${ }^{21}$ The resulting

\footnotetext{
${ }^{21}$ An end-point problem arises in the context of the HP-filter, which is a two sided filter. I have implemented the standard procedure which is to extend the sample (in this case by seven quarters) using an $\operatorname{ARIMA}(1,1,1)$ so the
} 
bilateral correlations of HP-filtered deviations of log GDP are then calculated for the 1990Q11997Q4 and 1999Q1-2012Q4 periods. The change in the correlation coefficients between the two subperiods is reported in Table 1.

The results indicate that correlation coefficients among the East Asian countries rise, sometimes significantly. In particular, China's correlation rises with most of the East Asian countries rise, and substantially so with Singapore and Japan - the latter is important to the extent that it matches the narrative of increasing linkages between the two economies. ${ }^{22}$ Note the exception is Indonesia, but in this case the result is probably an artifact of the sharp and permanent drop in the trend in Indonesian GDP in 1997. This event distorts the estimated business cycle obtained using the HP filter (as well as linear detrending). In fact, once one takes out the Indonesian entries, the dominant impression one obtains is that business cycle correlations have risen, often substantially. ${ }^{23} 24$

The HP filter is but one way of identifying business cycles; it tends to identify smaller cyclical deviations than those obtained using quadratic detrending. If one uses quadratic detrending, once again one obtains broadly similar results (as long as one ignores the Indonesian results). The intra-East Asia correlations typically rise in the more recent period. This characterization holds regardless of whether the sample ends of 2006 or 2012.

Using non-overlapping four quarter growth rates as a measure of business cycles, one obtains results similar to those obtained using the HP filter to define business cycles. Business cycle correlations have tended to rise, as summarized in Table 2. The exceptions involve

\footnotetext{
two sided filter can be implemented up to 2012Q4. A more economically substantive problem is that the recent observations are likely to be based upon preliminary data, while data earlier in the sample are likely to have undergone repeated benchmarking revisions.

22 If one expands the latter subsample to 2012, the business cycle correlations are typically higher, attributable to the common shock associated with the global recession.

${ }^{23}$ The fairly large change in the China-Philippine correlation probably reflects the end of shocks to the Philippine economy arising from political events. The China-Philippine correlation is actually negative in the early sample.

${ }^{24}$ Tempering the results, it's of note that the correlations also rise for Mexico and all other countries in the sample. On the other hand, most of the Mexico pre-crisis correlations were negative, or slightly positive (with Japan and United States), so that in the latter subperiod, the Mexico correlations are still modest.
} 
Indonesia, or involve very modest declines. If the later subsample is extended to 2012 , then the pattern is more pronounced.

It's notable that China's correlation rises in a noticeable fashion with Japan and Korea, using this definition of the business cycle. So too do correlations between Japan and Taiwan, as well as Singapore and Taiwan.

Typically, researchers have examined the static correlations as a way of explaining the strength of economic interactions. An alternative is to use an econometric methodology that allows for dynamics. I use a simple non-structural VAR to characterize the dynamics relating key variables to individual economies. Ideally, one would want to model all the economies simultaneously; however, there are not enough observations to undertake such an analysis using this approach. Hence, I use a more ad hoc approach, examining each East Asian country's dynamics separately. ${ }^{25}$

In each case I estimate a 2 lag VAR including the US, Japan, China and each respective East Asian country, using the indicated ordering. This means that I assume that all economic activity variables - in this case HP filter defined output gaps - are endogenous, but the US business cycle is more exogenous than Japan's, Japan's is more exogenous than China's, and China's is more exogenous than the cycle of the individual small East Asian economy. ${ }^{26}$

In order to conserve space, I present the detailed results for two of the larger economies of interest (Korea and Taiwan), and discuss the other economies' results in general terms. Korea and Taiwan are two countries which account for large shares of global imports used for exports. ${ }^{27}$ The resulting impulse response functions (IRFs) show the response of a variable to a one standard deviation shock to a particular variable. Plus/minus one standard

\footnotetext{
${ }^{25}$ An alternative approach would be to use a VAR incorporating more macro variables, such as interest or exchange rates, or employ a structural VAR. Given the brevity of the available subsamples, and the large number of parameters that would have to be estimated, I have opted for more parsimonious specifications. For an alternative approach, see Bussiere et al. (2012).

${ }^{26}$ This means a standard Cholesky decomposition is used, rather than restriction imposed by theory involving zero constraints.

${ }^{27}$ Baldwin and Lopez-Gonzalez (2013), Table 23. This characterization applies to 2009.
} 
error bands are included to illustrate the degree of statistical precision - or lack of - in each set of estimates.

In Figure 5.1, the graph in the first row of the first column denotes the response US GDP output gap to a shock to the US output gap, over time, during the 1981Q1-1997Q4 period. The hump shaped pattern indicates that after an initial positive impact, the response increases before decaying toward zero. The impulse response is statistically significant. The second figure in the first column shows the response of the Japanese output gap to the US output gap shock. As in the third and fourth figures (the Chinese and Korean output gaps), the output gap does not respond with statistical significance to US output shocks.

The second column shows the impulse response functions for shocks to the Japanese output gap, while the third and fourth show the corresponding functions for Chinese and Korean output gaps. One general characteristic of these figures is that only the impulse response functions in the diagonal elements display much statistical significance.

These results can be interpreted as indicating that whatever macroeconomic business cycle links there are between the US, Japan, China and Korea, they are not typically easy to detect in the pre-1997 sample.

For the 1999Q1-2007Q4 period (Figure 5.2), the IRFs provide a substantially different story. The Japanese output gap responds to the US output gap, as does the Korean. Now, Japanese and Korean output gaps respond to the Chinese output gap (borderline significance). In other words, China's business cycle has a noticeable impact on two other economies with which the vertical specialization links are particularly strong.

Given the strongly synchronized downturn in trade flows and economic activity in 200809, attributed by some to increasing vertical specialization, my prior was that extending the sample to incorporate the global recession would have strengthened these results. Surprisingly, the aforementioned effects largely disappear when the sample is extended up to 2012Q4 (results not shown). One interpretation of this phenomenon is that the effect of the vertical specialization linkages have been obscured by the divergence in macro policies, with Chinese 
GDP delinking from the rest of the global supply chain. The alternative view would allow that the measurement of the business cycle (i.e., output gap) as become much more problematic at the end of the sample period.

Next I consider Taiwan. In the early period (Figure 6.1), there are rarely any significant effects detected - most economies' output gaps appear to be affected by their own lagged output gaps. In this respect, the findings are similar to those obtained for Korea. In the more recent 1999Q1-2007Q4 period, Both Japanese and Taiwanese output gaps respond to the US output gap shock.

In contrast to the results for the earlier period, in the latter period (Figure 6.2), Taiwanese output responds positively to Chinese output, and with statistical significance at the 3-4 quarter horizon. The US appears to respond to China, even though it is treated as more exogenous than China; however the results are borderline significant. ${ }^{28}$ Once again, these results largely disappear once one extends the latter sample to $2012 \mathrm{Q} 4$.

A similar pattern of contrasting results hold for Singapore, Thailand and Malaysia. In the early period, most output gaps are largely explained by lagged own-economy output gaps. In the latter period, the output gaps respond to China's output gap, with borderline statistical significance (after accounting for US and Japan effects). The enhanced sensitivity of these countries' business cycles to China's is also detected in alternative global models (Bussiere, et al., 2012).

On the other hand, Indonesia and the Philippines do not exhibit any substantial change in IRFs, particularly of own output gap to Chinese output gap, moving from the early period to the later. It's conceivable that other factors obscure the relationship. For instance, Indonesia's intermediate exports to China, for instance, are substantial, but involve mostly energy exports. The Philippines experienced numerous political shocks during the 1980's and 1990's.

\footnotetext{
${ }^{28}$ The results regarding US-China interactions differ because the impulse response functions depend upon all the estimated parameters in the system of equations. In any case, the quantitative impacts are very similar.
} 
In sum, during this period when arguably global supply chains have become increasingly important, business cycle correlations have risen, and risen in a fashion mostly consistent with the pattern of linkages. Moreover, using a HP-filtered measures of the business cycle, it appears that in the period up to the onset of the global financial crisis, China's role in determining business cycles in East Asia grew. ${ }^{29}$ However, that evidence is less visible in the period spanning the global recession and the subsequent recovery.

\section{Exchange Rate Stabilization and the Chinese Dominance Thesis}

\subsection{Previous Assessments}

As vertical integration proceeds, it is likely that government reaction functions - in particular those of central banks - will evolve. One conjecture is that the extent that exchange rate movements complicate decision-making within the global supply chain, one would anticipate that policymakers experience pressure to stabilize exchange rates. ${ }^{30}$

On the other hand, it is unclear whether policymakers will want to stifle one key avenue of macroeconomic adjustment. For instance, Bems (2012) shows that increasing vertical specialization does not have unambiguous effects on the amount of exchange rate adjustment necessary to effect a given change in trade inflows. That's because accounting for intermediates means that countries are more closed than conventionally understood; but accounting for domestic intermediates means that economies are more open as services (which are typically thought of as untraded) are incorporated in exports.

Nonetheless, the conventional wisdom holds that policymakers will welcome more stable exchange rates when there is much production sharing. If they are to stabilize against each other, which currency will they stabilize against? There are several candidates historically, the U.S. dollar is the obvious candidate, due to its use as a financing and invoicing currency. But, with China's outsize role in trade transactions (and the supply chains), it seems

\footnotetext{
${ }^{29}$ For an assessment based upon imports for production, see Ahuja and Nabar (2012).

${ }^{30}$ For a practitioner's view on how exchange rate movements complicate the management of production chains, see Mahidhar (undated).
} 
reasonable to ask whether the regional central banks will coordinate to an ever greater extent on the Chinese yuan, much as European countries anchored their currencies to the Deutschemark some thirty years ago.

This hypothesis gains even more plausibility as Chinese authorities embark on a project to internationalize the RMB. The measures include allowing for RMB swaps, and encouraging invoicing in CNY. ${ }^{31}$

Figures 7 and 8 show the evolution of the regional currencies, including the Chinese yuan (CNY), expressed in terms of IMF Special Drawing Rights (SDRs), in the wake of the reform of the Chinese exchange rate regime in July 2005, and after the financial crisis, starting in July 2010. Notice that the currencies of the region appear to follow the Chinese yuan, suggesting that central banks in the region play close attention to Chinese currency interventions.

One way of making this assessment is to examine how daily currency movements are related to movements in the major currencies - the United States dollar (USD), the euro (EUR), the Japanese yen (JPY) - and the CNY (all expressed against the SDR). The regression coefficients are then interpretable as the weight ascribed to each currency in the currency basket targeted by the central bank.

$$
\begin{gathered}
\Delta e_{t}^{i / S D R}=\alpha_{0}+\alpha_{1} \Delta e_{t}^{U S D / S D R}+\alpha_{2} \Delta e_{t}^{C N Y / S D R}+\alpha_{3} \Delta e_{t}^{E U R / S D R}+\beta_{4} \Delta e_{t}^{J P Y / S D R}+ \\
\alpha_{5} \Delta e_{t}^{G B P / S D R}+u_{t}
\end{gathered}
$$

Where $e^{\cdot / S D R}$ is the number of currency units per SDR, in logs, the $i$ superscript denotes the specific East Asian currency of interest, and $\Delta$ is the first difference operator.

For instance, if $\alpha_{1}=1$ for $\mathrm{i}=\mathrm{KRW}$ (Korean won), then the interpretation would be that the Bank of Korea targeted the US dollar.

\footnotetext{
${ }^{31}$ See Chinn (2012) for a discussion of what prerequisites need to hold for internationalization of a currency, with special reference to the RMB and other emerging market currencies. Ito and Chinn (2013) examine the determinants of the use of the RMB as an invoicing currency.
} 
Huang, Wang, and Fan (2013) examine daily data from January 1999 to July 2005, and July 2005 to June 2013, for the Hong Kong dollar (HKD), Indian rupee (INR), Indonesian rupiah (IDR), Korean won (KRW), Malaysian ringgit (MYR), Singapore dollar (SGD), and Thai baht (THB), using equation (8). In all cases, the weight ascribed to the USD declines going from the first sample to the second, save the SGD and THB. Moreover, the estimated weight on the CNY becomes statistically significant. Those results confirm that at high frequencies (daily), the central banks have paid much more attention to movements in the CNY than they did before July 2005.

Fratzscher and Mehl (2012) use a variant of this approach. In their study, they assess the tripolar thesis - the idea that the USD, EUR and CNY are becoming the anchors for currency management - using daily data on nearly fifty exchange rates over the 1996 to 2011 period. They undertake two types of analyses; the first is an unconditional factor analysis, and the second, an extension of the first, augmented with policy announcements.

In the unconditional analysis, the authors regress changes in the exchange rates against the SDR on a US, euro area and regional factor, and other conditioning variables. The US factor (the US dollar/SDR exchange rate) is taken as exogenous, the euro factor is the residual from the regression of the euro exchange rate on the dollar rate, and the regional factor is a GDPweighted average of the regional currencies (excluding the CNY), orthogonalized by taking the residuals from a regression on the dollar and euro rates. ${ }^{32}$

Fratzscher and Mehl find that the regional factor is increasing in importance over time. Of course the US factor is dominant both pre- and post-reform (July 2005). The results for emerging Asia are reported in Figure 9. For the currencies of that region, the coefficient on the US factor is 0.74 and 0.60 , respectively. This means that after July 2005 , a $10 \%$ depreciation in the US dollar induces a $6 \%$ depreciation in a currency. The Asian regional factor coefficient increases from 0.19 to 0.25 .

\footnotetext{
32 The other conditioning factors are the three month USD Libor-US Treasury (TED) spread and the equity volatility index (VIX). These variables control for credit and liquidity risk.
} 
Of course, the interesting question is whether the CNY drives the regional factor. Using Granger causality tests, the authors find that pre-2005, one typically cannot reject the hypothesis that the CNY does not Granger-cause the regional factor; post-2005, one rejects the null. In addition, replacing the regional factor with the CNY rate yields similar results.

Fratzscher and Mehl then extend the analysis to include dummy variables for Chinese statements regarding increased flexibility or reserve diversification. The general pattern of factor loading estimates remains intact, while Chinese official announcements have a greater impact in the latter period. ${ }^{33}$

\subsection{Longer Term Trends and Exchange Rate Adjustment}

The preceding section outlined approaches that examined the behavior of exchange rates at high (daily) frequency. However, for macroeconomic interactions, one needs to know how the exchange rates behave over the longer term - monthly and quarterly. Not only are changes of interest, so too are levels.

In this section I attempt to redress this deficiency by examining how East Asian exchange rates have been managed in response to major currencies.

$$
\begin{gathered}
\Delta e_{t}^{i / S D R}=\beta_{0}+\beta_{1} e_{t-1}^{i / S D R}+\beta_{2} e_{t-1}^{U S D / S D R}+\beta_{3} e_{t-1}^{C N Y / S D R}+\beta_{4} e_{t-1}^{J P Y / S D R}+\beta_{5} F_{t-1}+ \\
\beta_{6} \Delta e_{t-1}^{i / S D R}+\beta_{7} \Delta e_{t-1}^{U S D / S D R}+\beta_{8} \Delta e_{t-1}^{C N Y / S D R}+\beta_{9} \Delta e_{t-1}^{J P Y / S D R}+\beta_{10} \Delta F_{t}+u_{t}
\end{gathered}
$$

Where $F$ is the financial stress index for the US.

This specification is an error correction model, which allows for a long run cointegrating relationship between the log levels of the six exchange rates against the SDR. The long run cointegrating relationship is given by the expression $-\beta_{k} / \beta_{1}$, while $\beta_{1}$ is an estimate of the rate

\footnotetext{
${ }^{33}$ Spencer (2013) takes issue with the yuan bloc thesis. He undertakes a more limited analysis, regressing exchange rates on four anchor currencies (US dollar, euro, yen, and Chinese yuan), and finds that post-2005, the dollar retains a high factor loading. There is a problem of interpretation, since the RMB is managed against the dollar, so movements adduced to the CNY might be more properly adduced to the dollar. Nonetheless, the importance of the dollar persists even after the yuan is orthogonalized against the other major currencies (although for Korean won and Malaysian ringgit, the yuan coefficient is larger than the corresponding dollar coefficient, so there does appear to be some evidence of a more prominent yuan bloc, even in this analysis).
} 
of reversion to long run equilibrium. Note the inclusion of the contemporaneous first difference of the financial stress index is consistent weak exogeneity of US financial stress. ${ }^{34}$

I estimate the specification in equation (10) over two samples, 1999M01 to 2005M06, and $2005 \mathrm{M} 07$ to $2013 \mathrm{M04}$, and examine the evolution of weights attached to the USD and the CNY going between the two subsamples. ${ }^{35}$ This break matches with the reform in the Chinese exchange rate regime. I don't include the HKD (since at this frequency it's collinear with the USD), but add in the New Taiwan dollar (NTD).

Note that the estimation of the error correction specifications is appropriate if the series are cointegrated. While the series do not appear to be cointegrated over the entire 1999M012013M04 period; do appear cointegrated over the subsamples, thus validating the estimation procedure that implemented.

Table 3 reports the results of estimating equation (10); the top half presents results pertaining to the early subsample, before the reform of the Chinese exchange rate regime. The bottom half applies to the later subsample.

Because the CNY is effectively pegged to the USD during the early period, it is not possible to identify a separate CNY effect. Hence, the only currencies included in the estimation in the early period are the USD and JPY. Nonetheless, it is still surprisingly difficult to identify a long run relationship between the currency values in the early subperiod. By and large the proportion of variation explained is nil, while there is some slight evidence of mean reversion, as evidenced by negative estimated $B_{1}$ coefficients. Because the fit is so poor, there is only weak evidence of a long run relationship between the various currencies and the USD and JPY (denoted by the US(LR) and JP(LR) entries).

In the bottom half of Table 3, the results suggest a much better fit. In all cases, there is evidence of reversion to long run relationships between the individual currencies, and the CNY, USD and JPY. For

\footnotetext{
34 The financial stress index is suppressed in the early subsample.

${ }^{35}$ I suppress inclusion of the US financial stress index in the early subsample, since it does not vary much.
} 
instance, the estimated $B_{1}$ ranges between 0.16 to 0.21 . This means the half-life of a deviation of the exchange rate from the long run relationship ranges from 3 to 4 months, ignoring short run dynamics.

For the cases where the coefficients are statistically significant, the CNY has taken on a more important role. For the SGD, the MYR and the THB, the Chinese currency is the dominant factor, as measured by the long run coefficient. In the case of the NTD, no currency seems to have an important impact; however, a slight variation in the specification (assuming US financial stress is not weakly exogenous with respect to the Taiwan currency) leads to a significant role for the Chinese currency.

One interesting counterexample is the KRW; in this case, the USD remains the most important factor. This is somewhat surprising, given the strong economic links to Japan and China. However, this outcome is consistent with Huang et al.'s (2013) results for daily data.

Bringing together the results from other studies and the preceding empirical exercise, it appears fairly clear that more currencies are becoming anchored to the CNY, particularly since the reform of China's exchange rate regime in 2005. Why this phenomenon is occurring cannot be determined within the context of these empirical studies, but one of the reasons is likely because in the context of an integrated supply chain, large exchange rate movements are unwelcome. With a lot of production costs located in China, it makes sense that the Chinese currency would serve as one of the nominal anchors for the region's currencies.

\section{Conclusion}

The increasing importance of global supply chains in East Asia has sparked substantial research tracing out the microeconomic and trade implications. The macroeconomics profession has been a relative latecomer to examining the implications for the transmission of price and output effects. Moreover, the ramifications for how policy reaction functions will evolve in response to the changing nature of trade linkages have only been touched upon. This survey suggests several conclusions.

First, the conventional means of measuring international competitiveness are going to be less and less adequate, as production becomes more fragmented. Relatedly, it will become less and less tenable to estimate the traditional partial equilibrium trade equations, in order to obtain macro-level trade elasticities, as mis-measurement of trade flows becomes more 
pronounced, and appropriate deflators for real exchange rates diverge further from the typically used deflators.

Second, the increasing role of vertical specialization will likely drive down exchange rate pass through. This is true even if the increase is due to increasing arms-length transactions. However, to the extent that pass through is less pronounced the greater the amount of intrafirm trade, a decrease in exchange rate pass through is likely to occur.

Third, business cycle correlations are rising throughout the region. The more prominent increases are often associated with China, a finding consistent with China's growing role in the global supply chain. Furthermore, the propagation of shocks throughout the East Asia system is consistent China driving movements in output, at least in Korea and Taiwan.

Finally, there is evidence that the central banks of the region are paying more heed to the Chinese currency's value. This is true at the high frequency (daily) and at lower frequency (monthly); it's true with respect to rates of depreciation, as well as levels currency values. Since these relationships are not structural, there is no guarantee that they will remain in place. At the same time, continued integration by way of production fragmentation should make central bankers pay extra heed to stabilizing currency values against each other. 


\section{References}

Ahuja, Ashvin, and Malhar Nabar, 2012, "Investment-Led Growth in China: Global Spillovers," IMF Working Paper No. 12/267 (November).

Amiti, Mary, Oleg Itskhoki, and Jozef Konings, 2012, "Importers, Exporters, and Exchange Rate Disconnect," mimeo (November 7).

Arkolakis, Costas, and Ananth Ramanarayanan. "Vertical Specialization and International Business Cycle Synchronization," The Scandinavian Journal of Economics 111, no. 4 (2009): 655-680.

Bailliu, Jeannine, and Eiji Fujii, 2004, "Exchange Rate Pass-Through and the Inflation Environment in Industrialized Countries: An Empirical Investigation," Bank of Canada Working Paper No. 2004-21.

Baldwin, Richard (editor), 2009, The Great Trade Collapse: Causes, Consequences and Prospects (London: CEPR).

Baldwin, Richard and Javier Lopez-Gonzalez, 2013, "Supply-Chain Trade: A Portrait of Global Patterns and Several Testable Hypotheses," NBER Working Paper No. 18957 (April).

Barrell, Ray and Stephane Dées, 2005, "World Trade and Global Integration in Production Processes: A Re-assessment of Import Demand Equations," ECB Working Paper No. 503 (Frankfurt: European Central Bank, July).

Bems, Rudolfs, 2012, "Intermediate Inputs, External Rebalancing and Relative Price Adjustment," mimeo.

Bems, Rudolfs, and Robert C. Johnson, 2012, "Value-added Exchange Rates," NBER Working Paper No. 18498 (October).

Berman, Nicolas, Philippe Martin and Thierry Mayer, forthcoming, "How Do Different Exporters React to Exchange Rate Changes?" Quarterly Journal of Economics 127 (1): 437-492.

Burstein, Ariel, Christopher Kurz, and Linda Tesar, 2008, Trade, production sharing, and the international transmission of business cycles', Journal of Monetary Economics 55(4), 775-795.

Bussiere, Matthieu, Alexander Chudik, and Giulia Sestieri, 2012, "Modelling Global Trade Flows: Results from a GVAR Model," Globalization and Monetary Policy Institute Working Paper No. 119 (Dallas: Federal Reserve Bank of Dallas, July).

Camarero, Mariam and Cecilio Tamarit, 2003, "Estimating the export and import demand for manufactured goods: The role of FDI," Leverhulme Center Research Paper Series No. 2003/34 (Nottingham: University of Nottingham).

Campa, Jose Manuel, and Linda S. Goldberg, 2005, "Exchange Rate Pass-Through to Import Prices," Review of Economics and Statistics 87(4), pp. 679-690. 
Chen, Hogan, Matthew Kondratowicz and Kei-Mu Yi, 2005, "Vertical Specialization and Three Facts about U.S. International Trade," North American Journal of Economics and Finance 16: 35-59.

Cheung, Yin-Wong, Menzie Chinn and Eiji Fujii, 2010, "China's Current Account and Exchange Rate," China's Growing Role in World Trade, edited by R. Feenstra and S.-J. Wei (U.Chicago Press for NBER).

Cheung, Yin-Wong, Menzie Chinn and XingWang Qian, 2012, "Are Chinese Trade Flows Different?" Journal of International Money and Finance 31(8): 2127-2146.

Chinn, Menzie, 2012, "A Note on Reserve Currencies with Special Reference to the G-20 Countries," paper written for the International Growth Centre (IGC), India Central Programme (May).

Chinn, Menzie, 2010, "Supply Capacity, Vertical Specialization and Trade Costs: The Implications for Aggregate U.S. Trade Flow Equations," Mimeo.

Chinn, Menzie, 2006, "A Primer on Real Effective Exchange Rates: Determinants, Overvaluation, Trade Flows and Competitive Devaluations," Open Economies Review 17(1): 115-143.

Choudhri, Ehsan and Dalia Hakura, 2012, "The Exchange Rate Pass-Through to Import and Export Prices: The Role of Nominal Rigidities and Currency Choice," IMF Working Paper No. 12226.

Dekle, Robert, Hyeok Jeong and Heajin Ryoo, 2011, "A Re-Examination of the Exchange Rate Disconnect Puzzle: Evidence from Firm Level Data," mimeo.

Devereux, Michael B., and Hans Genberg, 2007, "Currency Appreciation and Current Account Adjustment," Journal of International Money and Finance 26 (4): 570-86.

Di Giovanni, Julian, and Andrei Levchenko, 2012, "Putting the Parts Together: Trade, Verticla Linkages, and Business Cycle Comovement," American Economic Journal: Macroeconomics, 2(2): 95-124.

Fernald, John, Hali Edison, and Prakash Loungani, 1999, "Was China the First Domino? Assessing Links between China and Other Asian Economies," Journal of International Money and Finance 18 (4): 515 535.

Fratzscher, Marcel, and Arnaud Mehl, 2011, "China's dominance hypothesis and the emergence of a tripolar global currency system," ECB Working Paper No. 1392.

Ghosh, Amit, and Ramkishen S. Rajan, 2007, "A Survey of Exchange Rate Pass-Through in Asia," Asian-Pacific Economic Literature 21(2), 13-28.

Goldstein, Morris, and Mohsin Khan, 1985, Income and Price Effects in Foreign Trade, in R. Jones and P. Kenen (eds.), Handbook of International Economics, Vol. 2, (Amsterdam: Elsevier).

Gopinath, Gita, Oleg Itskhoki, and Roberto Rigobon, 2010, "Currency Choice and Exchange Rate PassThrough," American Economic Review 100(1): 304-336. 
Helkie, William and Peter Hooper, 1988, "The U.S. External Deficit in the 1980's: An Empirical Analysis," in R. Bryant, G. Holtham and P. Hooper (eds.) External Deficits and the Dollar: The Pit and the Pendulum. Washington, DC: Brookings Institution.

Hillberry, Russell and David Hummels, 2012, "Trade Elasticity Parameters for a CGE Model," in Peter B. Dixon \& Dale W. Jorgenson, ed., Handbook of Computable General Equilibrium Modeling (Elsevier Publishers).

Hooper, Peter, Karen Johnson and Jaime Marquez, 2000, "Trade Elasticities for the G-7," Princeton Studies in International Economics No. 87 (Princeton, NJ: Princeton University).

Huang, Yiping, Daili Wang Daili, and Gang Fan, 2013, "Paths to a Reserve Currency: Internationalization of RMB and Its Implications," paper prepared for the ADB Institute project Currency Internationalization Study: Lessons and Prospects for the RMB, August 8, 2013, Tokyo.

Hummels, David, Jun Ishii, and Kei-Mu Yi, 2001, "The Nature and Growth of Vertical Specialization in World Trade," Journal of International Economics 54: 75-96.

IMF, 2007, "Chapter 3: Exchange Rates and the Adjustment of External Imbalances," World Economic Outlook (IMF: Washington, D.C., April).

Ito, Hiro and Menzie Chinn, 2013, "The Rise of the "Redback" and China's Capital Account Liberalization: An Empirical Analysis on the Determinants of Invoicing Currencies," paper prepared for ADBI workshop "Currency Internationalization: Lessons for the RMB," Tokyo, August 8, 2013.

Jacks, David, Christopher Meissner and Dennis Novy, 2009, "Trade Booms, Trade Busts, and Trade Costs," mimeo (August).

Johnson, Robert C., forthcoming, "A Guide to Value-Added Export Data for Macroeconomic and Trade Research," Journal of Economic Perspectives.

Koopman, Robert, Zhi Wang, and Shang-Jin Wei, 2012, "Tracing Value-Added and Double Counting in Gross Exports," NBER Working Paper No. 18579.

Kose, M. Ayhan, and Kei-Mu Yi, 2001, "International trade and business cycles: is vertical specialization the missing link?" The American Economic Review 91(2): 371-375.

Mahidhar, Vikram, undated, "Managing in the Face of Exchange-Rate Uncertainty: A Case for Operational Hedging," A Deloitte Research Study.

Mann, Catherine and Plück, Katerina, 2007, "The US Trade Deficit: A Disaggregated Perspective," in R. Clarida (ed.), G7 Current Account Imbalances: Sustainability and Adjustment (U. Chicago Press). 
Marazzi, Mario, Nathan Sheets, Robert J. Vigfusson, and Jon Faust, Joseph E. Gagnon, Jaime Marquez, Robert F. Martin, Trevor A. Reeve, and John H. Rogers, 2005, "Exchange Rate Pass-through to U.S. Import Prices: Some New Evidence," International Finance and Discussion Papers No. 2005-833 (April) Neiman, Brent, 2010, "Stickiness, synchronization, and passthrough in intrafirm trade prices." Journal of Monetary Economics 57(3): 295-308.

Ng, Eric C.Y., 2010, "Production Fragmentation and Business-Cycle Comovement," Journal of International Economics 82: 1-14.

Parsley, David and Helen Popper, 2010, "Understanding Real Exchange Rate Movements with Trade in Intermediate Products," Pacific Economic Review 15(2), 171-188

Rose, Andrew K., 1991, "The role of exchange rates in a popular model of international trade : Does the 'Marshall-Lerner' condition hold?” Journal of International Economics 30(3-4): 301-316.

Sekine, Toshitaka, 2006, "Time-varying exchange rate pass-through: experiences of some industrial countries," BIS Working Paper No. 202 (March).

Spencer, Michael, 2013, "A 'yuan bloc' in Asia? Not yet," Global Economic Perspectives (New York: Deutsche Bank, 7 February).

Thorbecke, Willem, 2011, "The Effect of Exchange Rate Changes on Trade in East Asia," ADBI Working Paper No. 263 (January).

Thorbecke, Willem, 2006, "How Would an Appreciation of the Renminbi Affect the US Trade Deficit with China?" BE Press Macro Journal 6(3): Article 3.

Thorbecke, Willem and Gordon Smith, 2010, "How Would an Appreciation of the RMB and Other East Asian Currencies Affect China's Exports?" Review of International Economics 18 (1): 95-108.

UNCTAD, 2013, World Investment Report (UN: New York and Geneva).

Wang, Zhi and Shang-Jin Wei, 2010, "What Accounts for the Rising Sophistication of China's Exports?" China's Growing Role in World Trade, edited by Shang-Jin Wei and Rob Feenstra, (Chicago: University of Chicago Press), pp. 63-104.

Yi, Kei-Mu, 2003, "Can Vertical Specialization Explain the Growth of World Trade?" Journal of Political Economy 111(1): 53-102. 
Table 1: Change in Business Cycle Correlations, using Hodrick-Prescott Detrending

\begin{tabular}{|c|c|c|c|c|c|c|c|c|c|c|c|c|}
\hline Correlation & YDEVCH2 & YDEVJP & YDEVKO & YDEVTI & YDEVHK & YDEVID & YDEVMA & YDEVPH & YDEVSI & YDEVTH & YDEVUS & YDEVMX \\
\hline YDEVCH2 & 0.000 & & & & & & & & & & & \\
\hline YDEVJP & 0.821 & 0.000 & & & & & & & & & & \\
\hline YDEVKO & 0.088 & 0.262 & 0.000 & & & & & & & & & \\
\hline YDEVTI & 0.409 & 0.734 & 0.046 & 0.000 & & & & & & & & \\
\hline YDEVHK & -0.003 & 0.919 & 0.048 & 0.131 & 0.000 & & & & & & & \\
\hline YDEVID & -0.250 & 0.086 & -0.263 & -0.418 & -0.131 & 0.000 & & & & & & \\
\hline YDEVMA & 0.457 & 0.393 & 0.136 & 0.456 & 0.474 & -0.251 & 0.000 & & & & & \\
\hline YDEVPH & 0.838 & 0.287 & -0.126 & 0.112 & 0.118 & -0.035 & 0.002 & 0.000 & & & & \\
\hline YDEVSI & 0.510 & 0.613 & 0.074 & 0.721 & 0.455 & -0.421 & -0.042 & -0.047 & 0.000 & & & \\
\hline YDEVTH & 0.143 & 0.265 & -0.165 & 0.268 & 0.298 & -0.051 & -0.077 & -0.069 & -0.157 & 0.000 & & \\
\hline YDEVUS & 0.123 & 0.564 & 0.288 & 0.490 & 0.533 & -0.313 & 0.526 & 0.650 & 0.724 & 0.227 & 0.000 & \\
\hline YDEVMX & 0.779 & 0.443 & 0.807 & 0.726 & 0.767 & 0.054 & 0.515 & 0.545 & 0.777 & 0.366 & 0.711 & 0.000 \\
\hline
\end{tabular}

Green cells, values greater than 0.30 , yellow values smaller than -0.15 . 
Table 2: Change in Business Cycle Correlations, using Non-overlapping Four-quarter Growth Rates

\begin{tabular}{|c|c|c|c|c|c|c|c|c|c|c|c|c|}
\hline Correlation & D4YCH & D4YJP & D4YKO & D4YTI & D4YHK & D4YID & D4YMA & D4YPH & D4YSI & D4YTH & D4YUS & D4YMX \\
\hline D4YCH & 0.000 & & & & & & & & & & & \\
\hline D4YJP & 0.514 & 0.000 & & & & & & & & & & \\
\hline D4YKO & 0.465 & -0.103 & 0.000 & & & & & & & & & \\
\hline D4YTI & 0.201 & 0.338 & 0.264 & 0.000 & & & & & & & & \\
\hline D4YHK & 0.721 & 0.222 & -0.431 & 0.356 & 0.000 & & & & & & & \\
\hline D4YID & -0.046 & 0.579 & -0.036 & -0.462 & 0.289 & 0.000 & & & & & & \\
\hline D4YMA & 0.260 & -0.074 & 0.347 & 0.276 & 0.163 & -0.478 & 0.000 & & & & & \\
\hline D4YPH & 0.129 & -0.094 & -0.279 & 0.082 & 0.019 & 0.480 & -0.567 & 0.000 & & & & \\
\hline D4YSI & 0.215 & 0.060 & -0.071 & 1.073 & 0.542 & -0.138 & 0.302 & 0.139 & 0.000 & & & \\
\hline D4YTH & 0.199 & -0.003 & -0.525 & 0.318 & 0.149 & -0.121 & -0.378 & 0.048 & 0.229 & 0.000 & & \\
\hline D4YUS & -0.531 & -0.019 & 0.324 & 0.775 & 0.426 & -0.095 & 0.091 & 0.132 & -0.007 & 0.011 & 0.000 & \\
\hline D4YMX & -0.455 & 0.433 & 0.444 & -0.008 & 0.177 & -0.729 & -0.281 & -0.271 & 0.153 & -0.008 & 0.008 & 0.000 \\
\hline
\end{tabular}

Green cells, values greater than 0.30 , yellow values smaller than -0.15 . 
Table 3: Coefficients from Error Correction Model

\begin{tabular}{|c|c|c|c|c|c|c|}
\hline \multicolumn{7}{|c|}{ 1999M01-2005M06 } \\
\hline & KRW & SGD & NTD & IDR & MYR & THB \\
\hline \multirow[t]{2}{*}{$\mathrm{B}_{1}$} & $-0.117 \dagger$ & -0.110 & $0.141^{\dagger}$ & $-0.105^{\dagger}$ & -9.593 & -0.054 \\
\hline & $(0.075)$ & $(0.095)$ & $(0.075)$ & $(0.069)$ & (9.703) & $(0.064)$ \\
\hline \multirow[t]{2}{*}{ US } & -0.055 & 0.036 & $-0.173 * *$ & $0.129+$ & 9.557 & 0.006 \\
\hline & $(0.039)$ & $(0.052)$ & $(0.069)$ & $(0.082)$ & (9.705) & $(0.035)$ \\
\hline \multirow[t]{2}{*}{$J P$} & 0.045 & 0.040 & -0.038 & -0.112 & $0.052 * *$ & -0.005 \\
\hline & $(0.073)$ & $(0.031)$ & $(0.064)$ & $(0.132)$ & $(0.024)$ & $(0.065)$ \\
\hline Adj $R^{2}$ & 0.03 & 0.02 & 0.14 & 0.02 & 0.01 & -0.05 \\
\hline US(LR) & -0.47 & na & na & 1.23 & na & na \\
\hline$J P(L R)$ & 0.38 & na & na & -1.07 & na & na \\
\hline \multicolumn{7}{|c|}{ 2005M07-2013M04 } \\
\hline & KRW & SGD & NTD & IDR & MYR & THB \\
\hline \multirow[t]{2}{*}{$\mathrm{B}_{1}$} & $-0.160 * * *$ & $-0.167 * *$ & $-0.156^{* *}$ & $-0.212 * * *$ & $-0.204^{* *}$ & $-0.151 * * *$ \\
\hline & $(0.063)$ & $(0.074)$ & $(0.064)$ & $(0.064)$ & $(0.081)$ & $(0.053)$ \\
\hline \multirow[t]{2}{*}{$\mathrm{CN}$} & -0.019 & $0.176^{*}$ & 0.029 & -0.099 & $0.144^{*}$ & $0.171^{* *}$ \\
\hline & $(0.086)$ & $(0.091)$ & $(0.048)$ & (0.099) & $(0.082)$ & $(0.083)$ \\
\hline \multirow[t]{2}{*}{ US } & $0.247^{* *}$ & $-0.092 * *$ & 0.016 & -0.018 & -0.025 & -0.046 \\
\hline & $(0.108)$ & $(0.045)$ & $(0.058)$ & (0.109) & $(0.043)$ & $(0.057)$ \\
\hline \multirow[t]{2}{*}{$J P$} & -0.051 & -0.005 & $0.032 \dagger$ & 0.025 & -0.009 & -0.023 \\
\hline & $(0.051)$ & $(0.029)$ & $(0.024)$ & $(0.046)$ & $(0.027)$ & $(0.029)$ \\
\hline Adj $R^{2}$ & 0.55 & 0.15 & 0.30 & 0.32 & 0.07 & 0.04 \\
\hline $\mathrm{CN}(\mathrm{LR})$ & -1.19 & 1.05 & 0.19 & -0.47 & 0.71 & 1.13 \\
\hline US(LR) & 1.54 & -0.55 & 0.10 & -0.08 & 0.12 & -0.30 \\
\hline$J P(L R)$ & -0.32 & 0.03 & 0.21 & -0.12 & -0.04 & -0.15 \\
\hline
\end{tabular}

Notes: Coefficient estimates from equation (9). $B_{1}$ is coefficient on lagged level of dependent variable. $\mathrm{CN}, \mathrm{US}, \mathrm{JP}$ are coefficients on respective currency values. $\mathrm{CN}(\mathrm{LR}), \mathrm{US}(\mathrm{LR})$, and JP(LR) are implied long run elasticities. Bold Face entries indicate that both the long run and reversion coefficient used to calculate the long run elasticities are statistically significant at the $10 \% \mathrm{msl}$. 


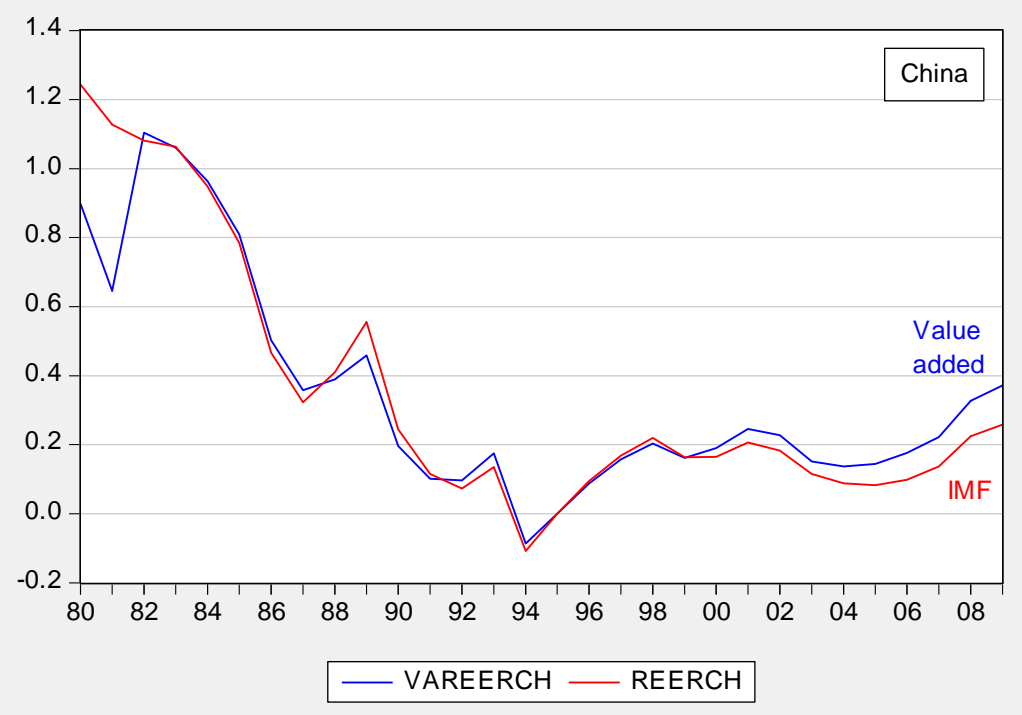

Figure 1. Real effective exchange rates for China

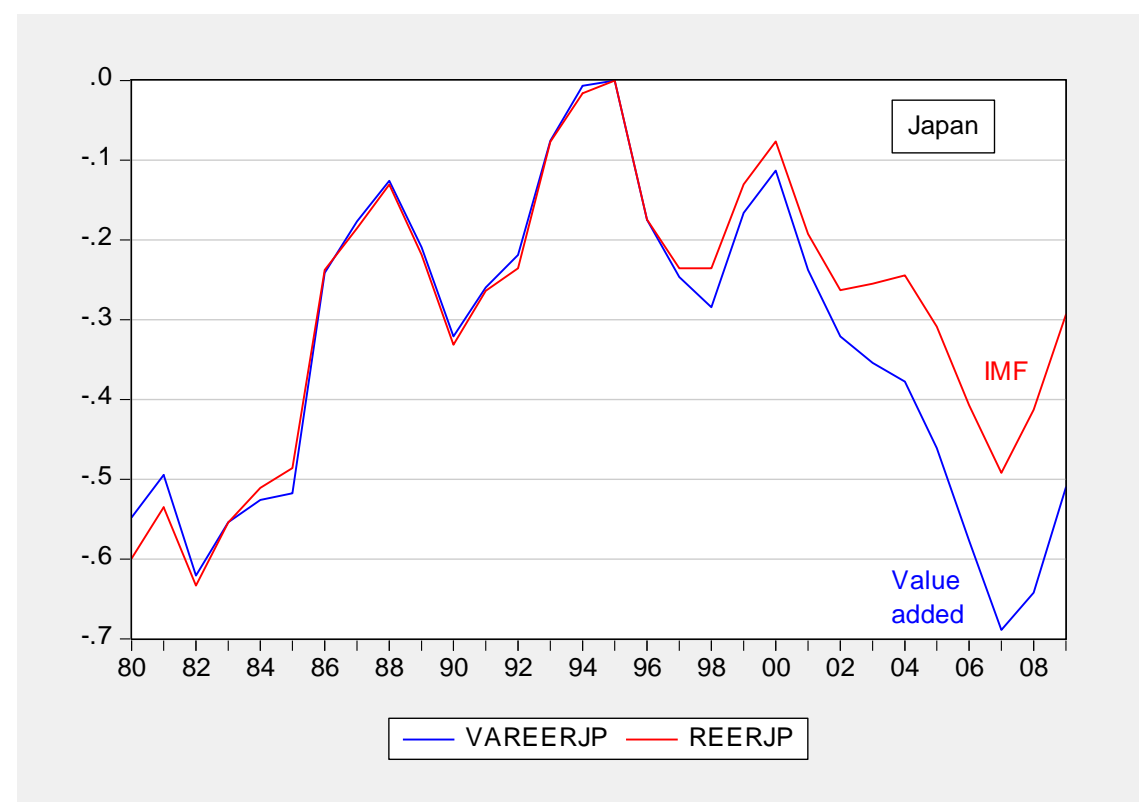

Figure 2. Real effective exchange rates for Japan 


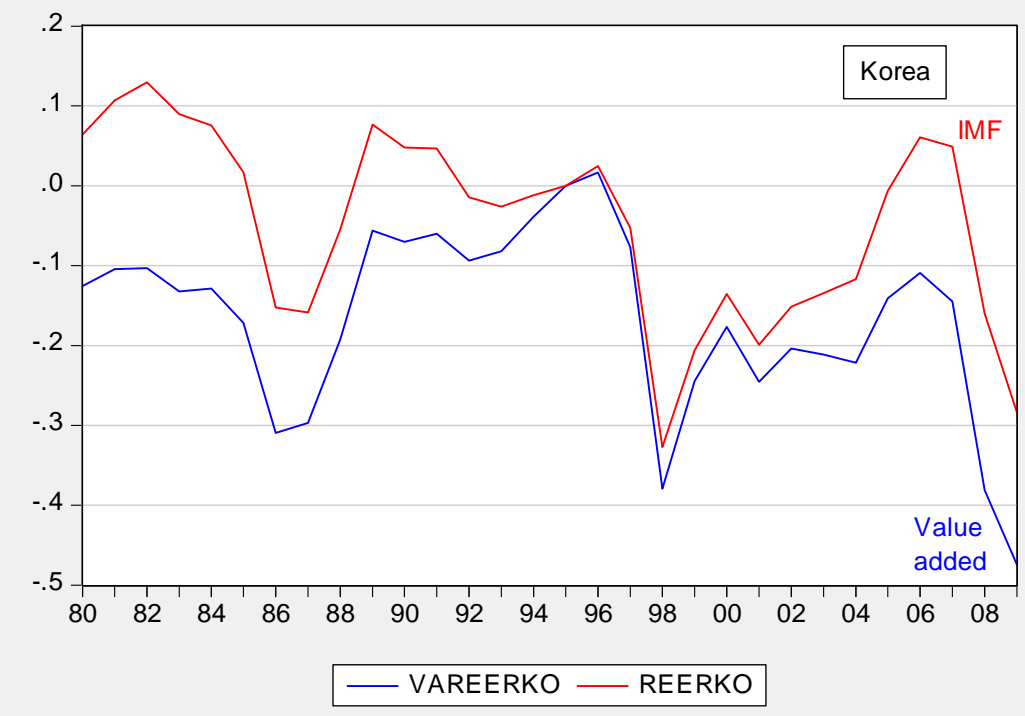

Figure 3. Real effective exchange rates for Korea

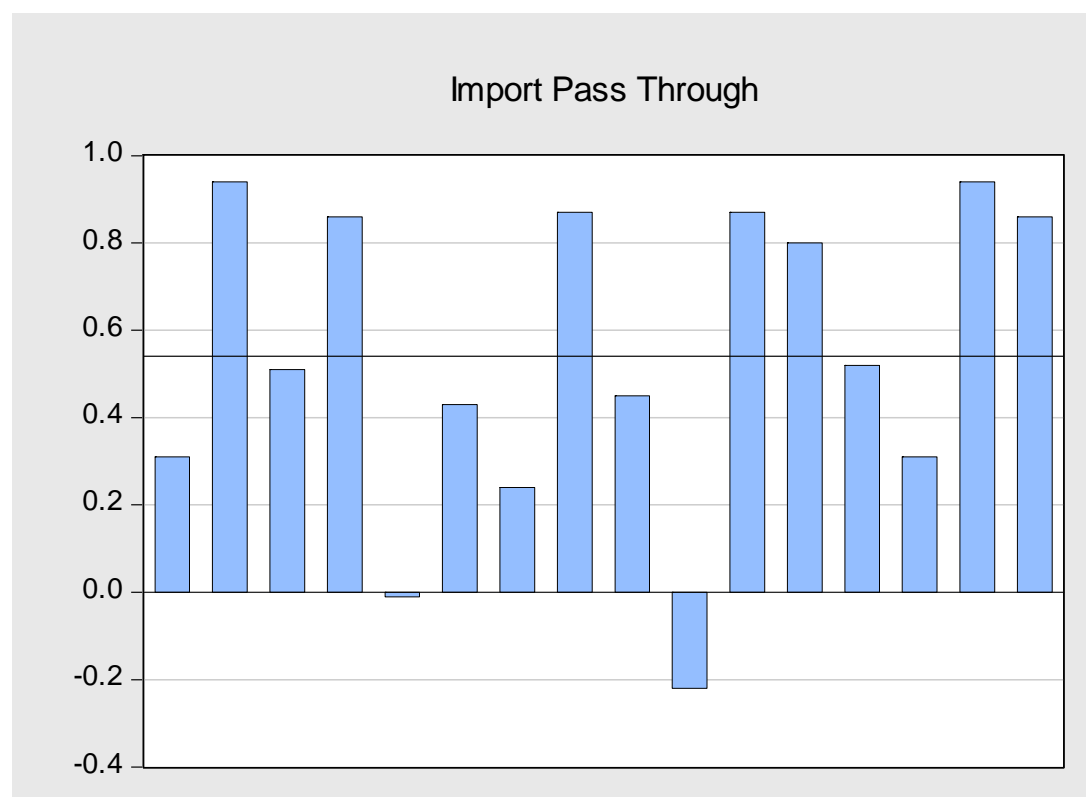

ZAF ARG COL BRA MEX JOR HKG KOR PAK SNG THA PER HUN POL TUR CHL

Figure 4.1. One quarter exchange rate pass through for emerging market imports. Source: Choudhri and Hakura (2012). 


\section{Export Pass Through}

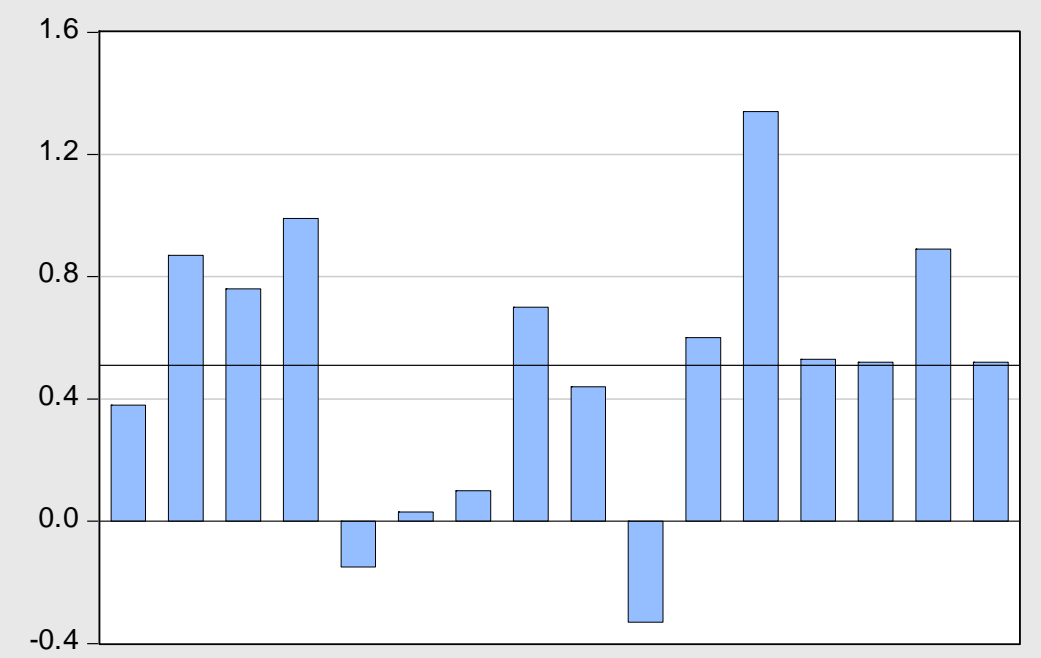

ZAF ARG COL BRA MEX JOR HKG KOR PAK SNG THA PER HUN POL TUR CHL

Figure 4.2. One quarter exchange rate pass through for emerging market exports. Source: Choudhri and Hakura (2012). 


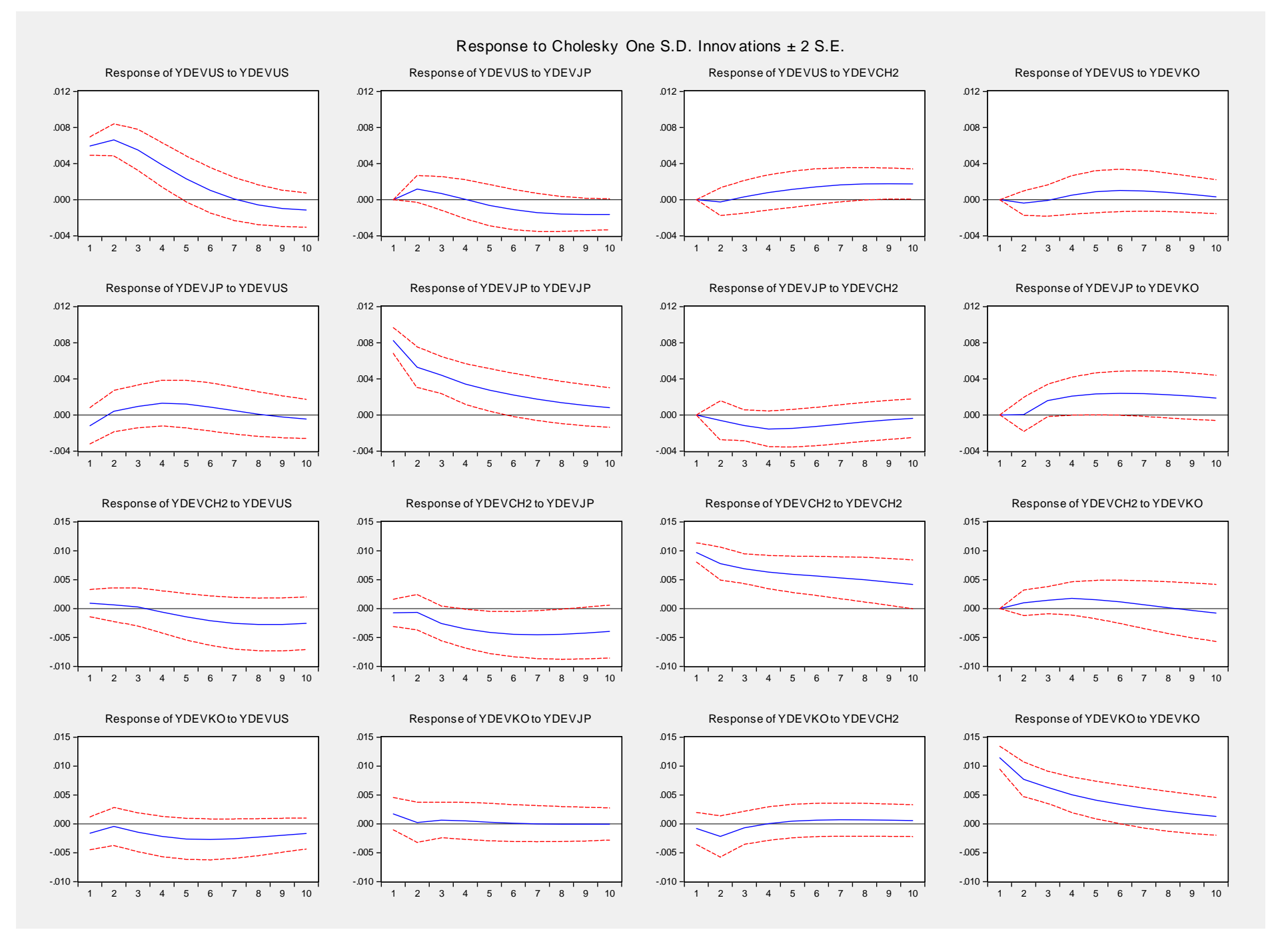

Figure 5.1. Impulse Response Functions for Korea VAR, 1981q1-1997q4 


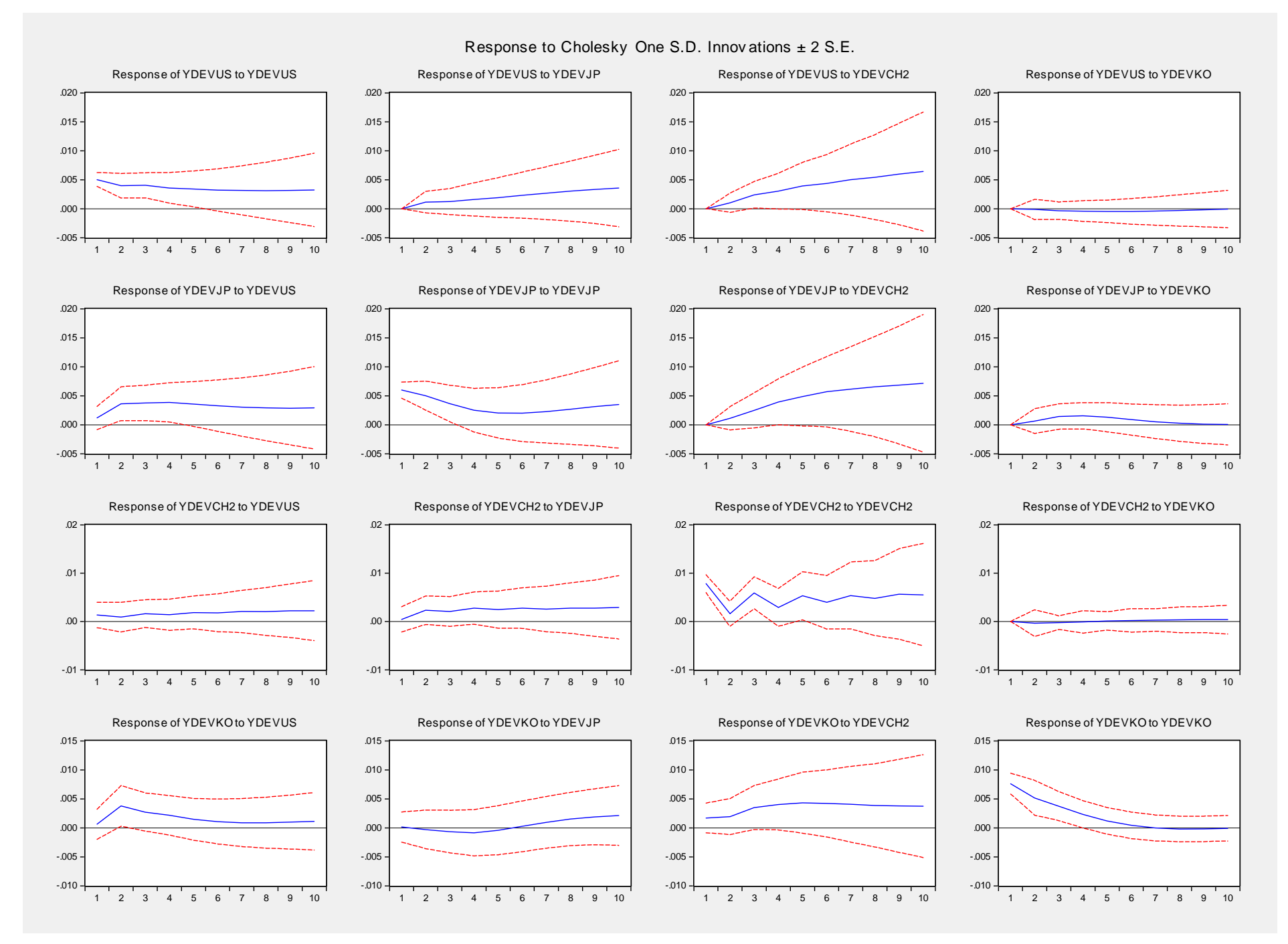

Figure 5.2. Impulse Response Functions for Korea VAR, 1999q1-2007q4 


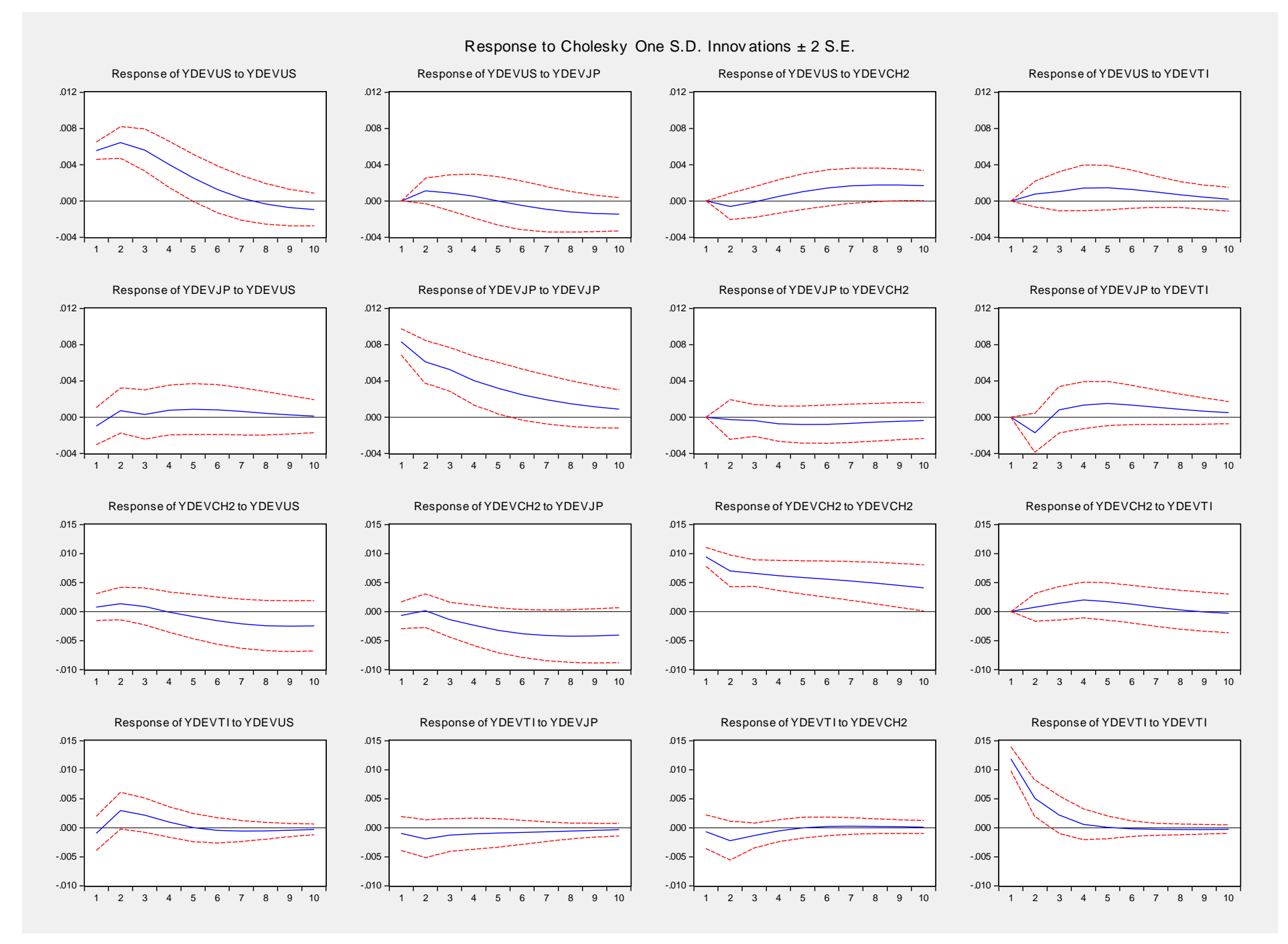

Figure 6.1. Impulse Response Functions for Taiwan VAR, 1981q1-1997q4 


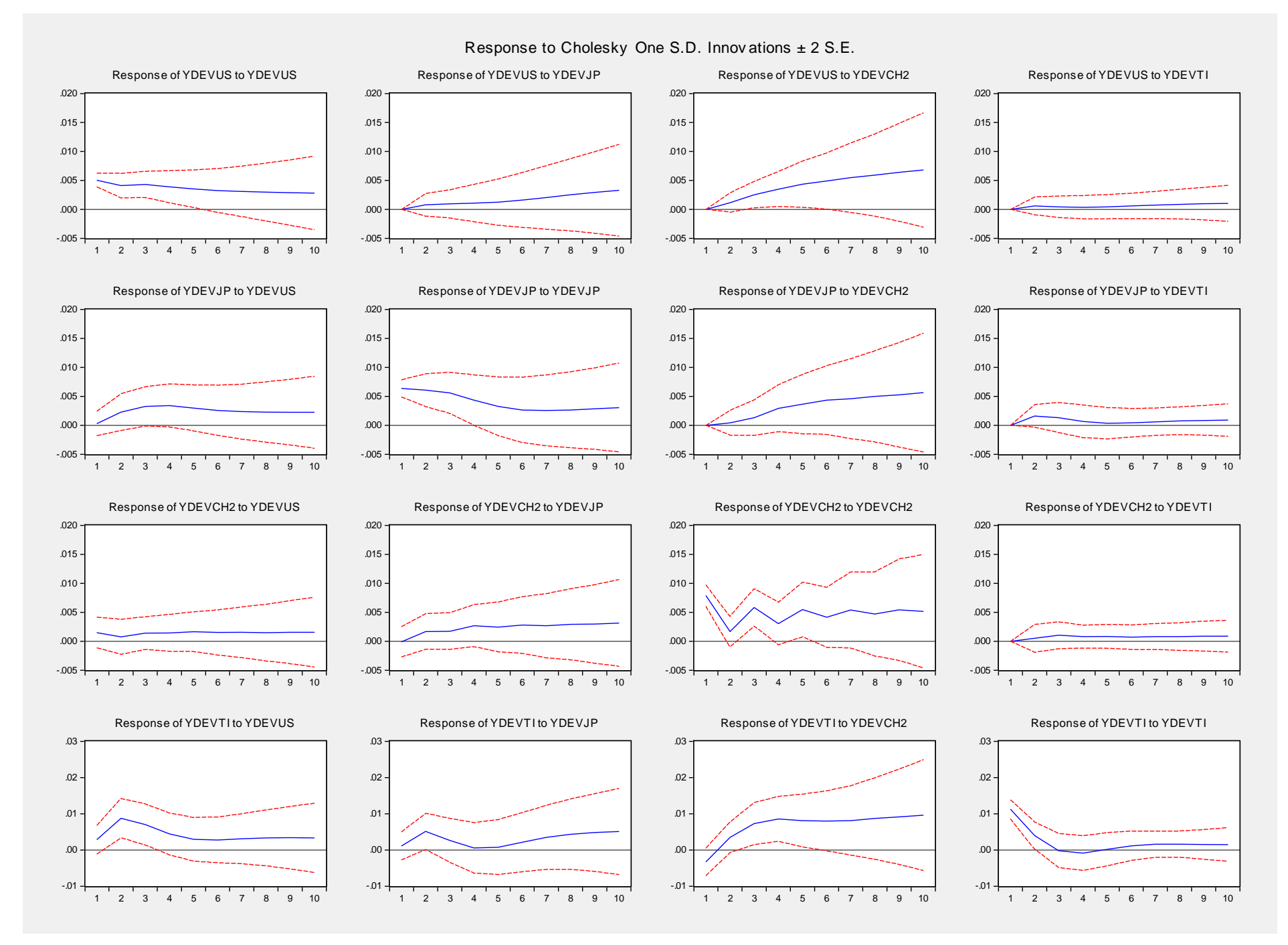

Figure 6.2. Impulse Response Functions for Taiwan VAR, 1999q1-2007q4 


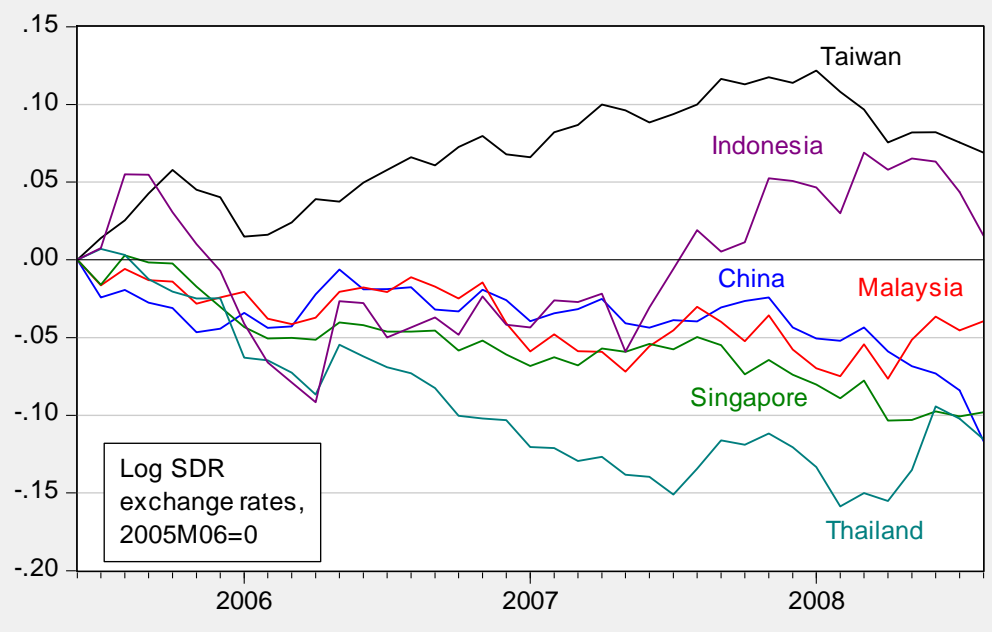

Figure 7. Log exchange rates against SDR, 2005M06=0.

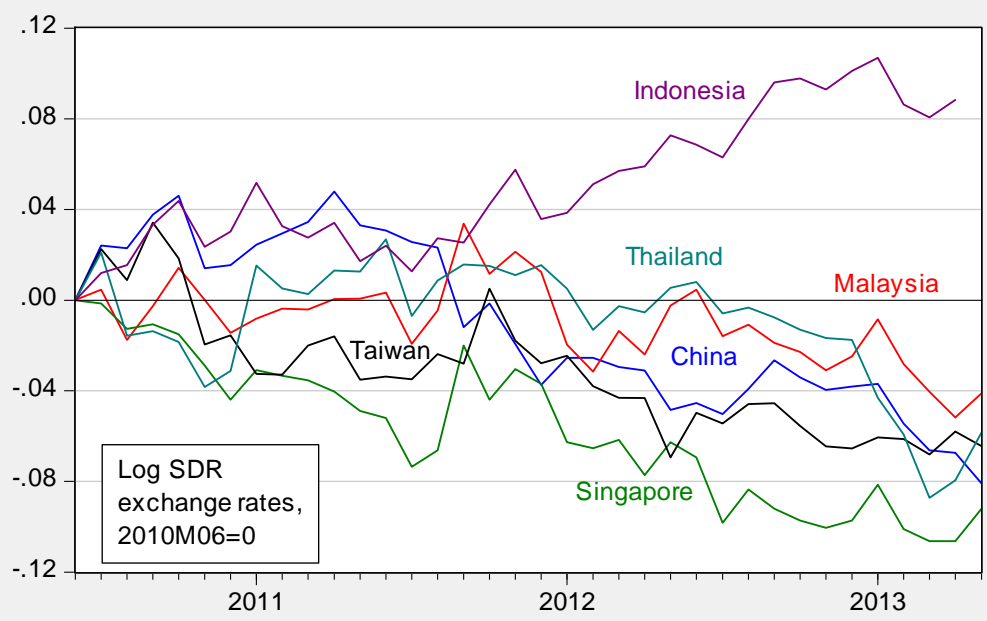

Figure 8. Log exchange rates against SDR, 2010M06=0. 


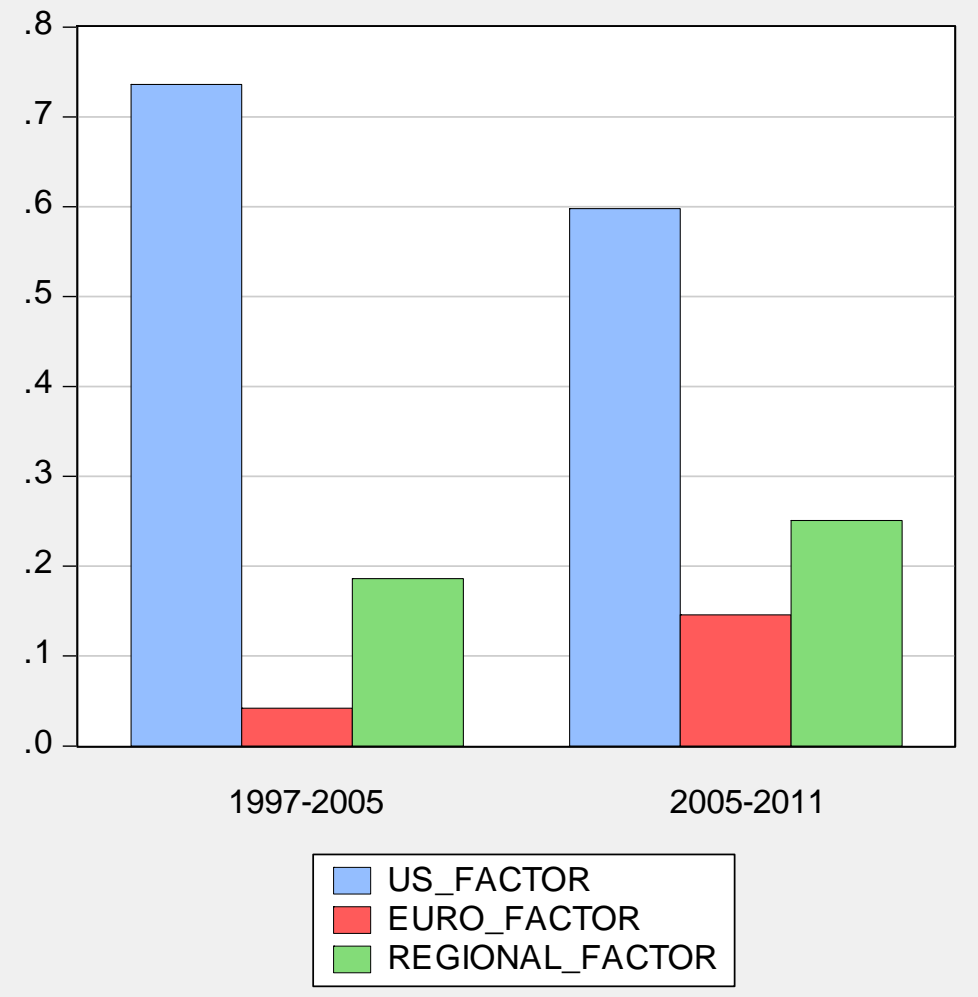

Figure 8. Determinants of East Asian Currency Movements, 1997-2011. Source: Fratzscher and Mehl (2011), Table 6. 


\section{Data Appendix}

\section{Section 2}

Exchange rates: VAREER and REER_INS from Bems and Johnson (2012).

\section{Section 3}

Data on exchange rates, GDP, trade flows, from Cheung, Chinn and Qian (2012).

\section{Section 4}

Quarterly real GDP in local currency, from IMF, International Financial Statistics, except Euro area GDP from ECB, and Korean GDP from OECD via FRED, and Chinese GDP pre-2000 from Cheung, Chinn and Fujii (2010).

Malaysian GDP starts in 1988, Thai GDP in 1993, Singapore GDP begins in 1983Q2, Indonesian GDP starts in 1997, Taiwanese GDP data in 1981. Annual data from IMF, World Economic Outlook (April 2013) spliced to all series except Taiwan using regressions in logs, where annual data is interpolated via quadratic match average. All GDP series except US, Japan, Korea, Euro area, and UK, seasonally adjusted using ARIMA X-12 applied to logged values.

HP detrending uses default $\lambda=1600$ for quarterly data; end point problem addressed by using $\operatorname{ARIMA}(1,1,1)$ to project out seven quarters, before HP filter is applied. For Indonesia, the ARIMA is applied only to the 1997-2013Q1 sample.

\section{Section 5}

Exchange rates: Bilateral SDR exchange rates from IMF, International Financial Statistics (end of period). Euro/dollar exchange rates from ECB. New Taiwan dollar from Bank of China.

Financial stress indices from IMF (personal communication). 